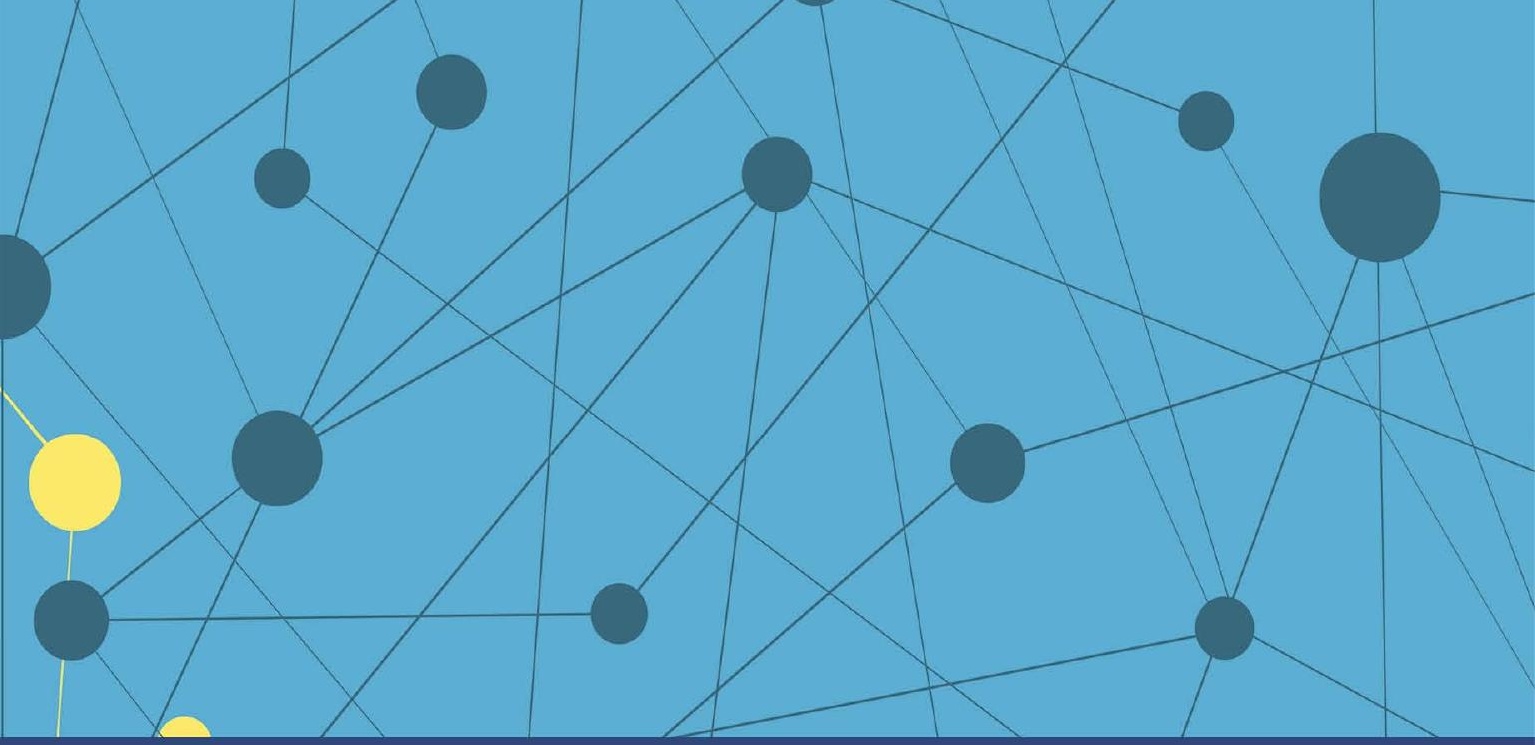

Routledge Frontiers of Criminal Justice

\title{
CRIMINAL JUSTICE AND \\ REGULATION REVISITED
}

ESSAYS IN HONOUR OF PETER GRABOSKY

Edited by

Lennon Y.C. Chang and Russell Brewer 


\section{Criminal Justice and Regulation Revisited}

This volume brings together leading researchers to celebrate the significant contributions of Peter Grabosky to the field of Criminology, and in particular his work developing and adapting regulatory theory to the study of policing and security.

Over the past three decades, his path-breaking theoretical and empirical research has contributed to a burgeoning literature on the myriad ways regulatory systems drive state and non-state interactions in an effort to control crime. This collection of essays showcases Grabosky's pioneering treatment of key regulatory concepts as they relate to such interactions, and illustrate how his work has been instrumental in shaping contemporary scholarship and practice around the governance of security.

Revisiting the work of a key figure in the field, this book will be of interest to criminologists, sociologists, socio-legal studies and those engaged with security and policy studies.

Lennon Y.C. Chang is a Senior Lecturer in Criminology at Monash University, Australia.

Russell Brewer is a Senior Lecturer in Criminology at Flinders University, Australia. 
Routledge Frontiers of Criminal Justice

\section{Moral Issues in Intelligence-led Policing}

Edited by Nicholas R. Fyfe, Helene O. I. Gundhus and Kira Vrist Rønn

The Enforcement of Offender Supervision in Europe

Understanding Breach Processes

Edited by Miranda M. Boone and Niamh Maguire

\section{Diversion in Youth Justice}

What Can We Learn from Historical and Contemporary Practices?

Roger Smith

\section{Police-Citizen Relations Across the World}

Comparing sources and contexts of trust and legitimacy

Edited by Dietrich Oberwittler and Sebastian Roché

\section{Privatising Punishment in Europe?}

Edited by Tom Daems and Tom Vander Beken

\section{Critical Perspectives on Coercive Interventions}

Law, Medicine and Society

Edited by Claire Spivakovsky, Kate Seear and Adrian Carter

\section{The Anthropology of Police}

Edited by Kevin G. Karpiak and William Garriott

Criminal Justice and Regulation Revisited

Essays in Honour of Peter Grabosky

Edited by Lennon Y.C. Chang and Russell Brewer

For more information about this series, please visit: www.routledge.com/ Routledge-Frontiers-of-Criminal-Justice/book-series/RFCJ 


\section{Criminal Justice and Regulation Revisited}

Essays in Honour of

Peter Grabosky

Edited by Lennon Y.C. Chang and Russell Brewer

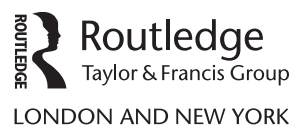


First published 2018

by Routledge

2 Park Square, Milton Park, Abingdon, Oxon OXI4 4RN

and by Routledge

7II Third Avenue, New York, NY I00I7

Routledge is an imprint of the Taylor \& Francis Group, an informa business

(C) 2018 selection and editorial matter, Lennon Y.C. Chang and

Russell Brewer; individual chapters, the contributors

The right of Lennon Y.C. Chang and Russell Brewer to be identified as the authors of the editorial matter, and of the authors for their individual chapters, has been asserted in accordance with sections 77 and 78 of the Copyright, Designs and Patents Act 1988.

All rights reserved. No part of this book may be reprinted or reproduced or utilised in any form or by any electronic,

mechanical, or other means, now known or hereafter invented, including photocopying and recording, or in any information storage or retrieval system, without permission in writing from the publishers.

Trademark notice: Product or corporate names may be trademarks or registered trademarks, and are used only for identification and explanation without intent to infringe.

British Library Cataloguing-in-Publication Data

A catalogue record for this book is available from the British Library

Library of Congress Cataloging-in-Publication Data

A catalog record has been requested for this book

ISBN: 978-I - I 38-04203-2 (hbk)

ISBN: 978-I-3I5-I7404-4 (ebk)

Typeset in Bembo

by Wearset Ltd, Boldon, Tyne and Wear 
For Peter Nils Grabosky, an inspiring teacher, colleague and friend 


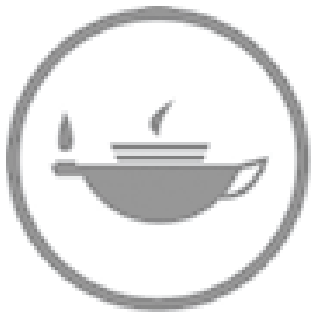

Taylor \& Francis Taylor \& Francis Group

http://taylorandfrancis.com 


\section{Contents}

List of illustrations

Notes on contributors

Preface: that light on the hill

JOHN BRAITHWAITE

Acknowledgements

\section{PART I}

Setting the scene

1 Peter Grabosky: at the interface of criminal justice and regulation

RUSSELL BREWER AND LENNON Y.C. CHANG

\section{PART II}

State as sponsors of regulatory activity

2 Regulation beyond the state: the role of non-state actors LORRAINE CHERNEY AND ADRIAN CHERNEY

3 Meta-regulating transnational environmental crime for better outcomes

\section{PART III}

Second and third parties as sponsors of regulatory activity

4 Regulating through enrolment: emerging conceptions of police as public health interventionists 
5 Co-producing prosecution: old and new third party forms ROBYN HOLDER

6 Non-state actors as brokers of crime control: accounting for entrepreneurialism on the waterfront RUSSELL BREWER

7 Using regulatory pluralism to achieve effective control of Somali piracy: a model for other piracy-prone regions

JADE LINDLEY

8 Old wine, opaque bottles? Assessing the role of Internet intermediaries in the detection of cybercrime

GREGOR URBAS

9 Internet vigilantism: co-production of security and compliance in the digital age

LENNON Y.C. CHANG

\section{PART IV}

New regulatory dimensions

10 The global anti-cybercrime network: mapping the polycentric regulation of online harms

BENOÎT DUPONT

\section{Conclusions}

LENNON Y.C. CHANG AND RUSSELL BREWER

Epilogue - Peter Nils Grabosky

RODERIC BROADHURST 


\section{Illustrations}

\section{Figures}

1.1 The three-dimensional pyramid

6.1 Example of policing agency undertaking a brokerage function

6.2 Active partnerships on Melbourne's waterfront 92

10.1 The network of international police cooperation initiatives against cybercrime (2014)

\section{Tables}

1.1 Regulatory forms 7

2.1 Phases of EGM regulatory change in Queensland 26

3.1 Technologies of third party co-production with respect to the illegal wildlife trade $\quad 40$

6.1 Organisations involved in the authorisation/delivery of security on Melbourne's waterfront

6.2 Measures of centrality and brokerage on Melbourne's waterfront

7.1 Global piracy attacks, 1992 to 2016

10.1 Types of organisational actors participating in the 51 anti-cybercrime initiatives

10.2 Organisational actors and initiatives ranked according to their centrality scores 


\section{Contributors}

Julie Ayling is a Visiting Research Fellow in the School of Regulation and Global Governance (RegNet) at the Australian National University (ANU) and a Visiting Fellow in the Department of Law at the European University Institute (EUI) in Florence, Italy. Her work centres on criminal networks and state responses (laws, policies and policing strategies), particularly in the context of transnational environmental crime. She has worked closely with Peter Grabosky on several projects, and has cowritten a number of publications with him, including a book (J. Ayling, P. Grabosky and C. Shearing, Lengthening the Arm of the Law: Enhancing Police Resources in the Twenty-First Century, Cambridge University Press, 2009).

John Braithwaite is a Professor and Founder of the School of Regulation and Global Governance (RegNet). He is leading a 25-year Peacebuilding Compared project that seeks to code 700 variables for all the world's major armed conflicts since the end of the Cold War. His latest book is Cascades of Violence (with Bina D'Costa, 2018). In criminology his work on restorative justice is one of his best known contributions, and in regulatory studies his works on responsive regulation and the globalisation of regulation are well known. He has co-authored many books and articles with Peter Grabosky.

Russell Brewer is a Senior Lecturer in Criminology at Flinders University. He completed his PhD under Peter Grabosky's supervision at the Australian National University. His research interests include policing, crime prevention, Internet crime, and social networks. In particular, his work seeks to establish the significance of networks as a tool for providing a clearer understanding of the risk factors that lead to deviance, as well as the structural characteristics of policing responses to criminality. He has published his findings through several leading publication outlets, holds multiple nationally competitive grants, and has been called upon by Government Agencies both domestically and abroad to advise on policy.

Roderic Broadhurst is a Professor of Criminology, School of Regulation and Global Governance (RegNet), Fellow Research School of Asian 
Studies, Australian National University (ANU). He is Director of the ANU Cybercrime Observatory and non-residential fellow of the Korean Institute of Criminology, and foundation editor of the Asian Journal of Criminology. Recent books include Business and the Risk of Crime in China (ANU Press, 2011), Policing in Context (Oxford University Press, 2009) and Violence and the Civilizing Process in Cambodia (Cambridge University Press, 2015).

Lennon Y.C. Chang is a Senior Lecturer in Criminology in the School of Social Sciences at Monash University, Australia. He is affiliated with the International Cybercrime Research Centre at Simon Fraser University and Cybercrime Observatory at the Australian National University. He is a cofounder and vice-chairman of the Asia Pacific Association of Technology and Society. His research is focused on the regulation and governance of cyberspace in the Asia-Pacific region. His book Cybercrime in the Greater China Region: Regulatory Responses and Crime Prevention (Edward Elgar, 2012) is about the nature and range of responses to cybercrime between China and Taiwan. He is currently researching Internet vigilantism in Asia. He is also working with governments and NGOs in ASEAN countries on research and training programmes to build cybersecurity capacity and awareness.

Adrian Cherney is an Associate Professor in the School of Social Science at the University of Queensland. He is also an Australian Research Council (ARC) Future Fellow. He has completed research on policing and regulation. His current work focuses on countering violent extremism (CVE) and is undertaking research on the supervision of terrorist offenders who have been released into the community on parole. His ARC Future Fellowship is exploring community-based efforts to prevent terrorism. Projects include identifying available data sources and measures for CVE evaluation. His research has also focused on community cooperation in counter-terrorism and police engagement of Muslim communities in counter-terrorism efforts. He has secured grants from the Australian Research Council, the US Air Force, the Australian Institute of Criminology, the Queensland Department of Communities, NSW Corrective Services and the Commonwealth Attorney General's Department.

Lorraine Cherney is currently completing a $\mathrm{PhD}$ in the School of Political Science and International Studies, at the University of Queensland. Her $\mathrm{PhD}$ is focused on the development of regulation and policy on gambling, with a particular focus on Electronic Gaming Machines. Lorraine was employed for eight years in the Queensland public service, and during that time worked for the Queensland Office of Regulatory Policy and the Queensland Office of Liquor and Gaming Regulation. This has included working with gambling providers and industry peak bodies to 
encourage and measure compliance to a voluntary responsible gambling code of practice. She was also a senior research officer at the Australian National University, Centre for Gambling Research (RegNet) where she completed research on the use of cash facilitates in gaming venues, and help seeking behaviours of problem gamblers and their friends and family members. Lorraine has also worked on funded projects examining interactive gaming in Australia.

Benoît Dupont is a Professor of Criminology at the Université de Montréal, where he also holds the Canada Research Chair in Cybersecurity. He is the Scientific Director of the Smart Cybersecurity Network (SERENERISC), one of Canada's Networks of Centres of Excellence. His research interests include the governance of security and the use of networked initiatives to enhance online safety, the coevolution of crime and technology, as well as the international comparison and evaluation of effective and efficient cybersecurity policies.

Robyn Holder is a Postdoctoral Research Fellow at Griffith University. Her work examines the relationship between victims and the state, and the mediating effect of rights. Current projects include an examination of third party advocacy structures in international and domestic criminal justice systems, and innovative justice and service responses to violence against women. She completed her $\mathrm{PhD}$ at the Regulatory Institutions Network at ANU in 2013 after nearly 30 years' experience in research, public policy and law reform in Australia and the UK.

Jade Lindley is an academic at the University of Western Australia Law School and Oceans Institute. Jade is a criminologist who specialises in transnational organised crime, international law and regulation. Her research crosses several themes in these contexts, including maritime piracy, human trafficking and fraud. Jade completed her $\mathrm{PhD}$ at The Australian National University, with visiting periods at the Institute of Criminology, University of Cambridge and the Maritime Knowledge Centre, International Maritime Organization. She has several publications and her book Somali Piracy: A Criminological Perspective was published in 2016.

Gregor Urbas is an Associate Professor of Law at the University of Canberra, where he teaches Criminal Law and Procedure, Cybercrime and Evidence Law. He has written extensively on criminal justice issues. He previously held positions at the Australian National University (ANU), the Australian Institute of Criminology (AIC) and the Law Council of Australia, and is an Adjunct Associate Professor at the ANU College of Law and at Simon Fraser University in Vancouver, Canada. Dr Urbas is currently a Visiting Fellow at the Tilburg Institute for Law, Society and Technology (TILT) at Tilburg University in the Netherlands. 
Jennifer D. Wood is a Professor in the Department of Criminal Justice, Temple University (Philadelphia, USA). She earned a bachelor's degree in Criminology at the University of Ottawa and received both an MA and $\mathrm{PhD}$ in Criminology from the University of Toronto (Canada). She is a criminologist with expertise in policing and regulation. Her research focuses on street-level interventions by police and other local entities in the management of health risk behaviours and social vulnerabilities. She is the North American Regional Editor for Policing and Society: An Internal Journal of Research and Policy. 


\section{Preface}

\section{That light on the hill}

Peter Grabosky has been an intellectual light on the hill for young scholars across the decades. His inspiration is on display in this volume through the work of his former students and colleagues. It is a unique kind of volume that achieves a high level of integration and integrity of focus. This is accomplished through a group of former ANU students and colleagues interrogating aspects of their own research that say something about the core themes in the life work of one scholar. I argue that this works because those themes are interesting and important, and the life of Peter Grabosky, boy and man, likewise is interesting and important.

While this book is about the percolation of Graboskism into the work of a new generation, we can better understand that by seeing what happened before. Peter has also been a mentor and a profound influence on his senior colleagues, me included, throughout his career. This started early on. It is best illustrated with the profound importance of the contribution Peter Grabosky made to the life work of Ted Gurr, who died just two weeks before I started writing this preface. Ted was an influence from the early days of his training. Peter became a post-doc working on the project Ted Gurr led on The Politics of Crime and Conflict (Gurr et al., 1977). This was a follow-up to Ted's pathbreaking cross-national work, Why Men Rebel (Gurr, 1970).

Path-breaking is no understatement, because Ted Gurr became the great methodological innovator of comparativism in political science, in criminology and in the social sciences broadly (Stohl, Lichbach and Grabosky, 2017). The Gurr comparative oeuvre combined quantitative comparison from diverse statistical primary sources with qualitative case study methods and historiography. Thankfully for Australia, Ted assigned Peter the job during his post-doc of collecting the historical data on patterns of crime and violence in the city of Sydney during the nineteenth and twentieth centuries. Peter fell in love with Australia and in 1978 became the first Director of the South Australian Office of Crime Statistics. He was incredibly energetic and his arrival was a shock to the relaxed Australian criminology scene of 1978. He always wore a suit (very odd), was rather handsome, appearing in his glasses like Clark Kent emerging from a telephone box. Earlier, he had started a love affair with Asia and the 
Pacific more widely - particularly, but not only, Japan - during his Vietnam War service on the USS Providence. The war itself he came to detest. The cynicism it engendered in him about abuse of state power began the process of turning him into a great scholar of state crime. He studied Japanese for decades with great assiduousness and limited success. His talents were not as a linguist. But Peter Grabosky was never a scholarly careerist; he followed his passion for learning wherever that passion burnt brightest, not where the investment would deliver him career success. Thankfully, he never attended ECR (Early Career Researcher) strategic development workshops.

When Peter imbibed Ted Gurr's passion for comparativism, however, he transformed it into something richer and better. Without the way Peter threw himself into The Politics of Crime and Conflict (Gurr et al., 1977) and Sydney in Ferment (Grabosky, 1977), the comparativism that made Gurr such a stellar paradigm-changer across the social sciences would never have been realised. In the next decade, Peter likewise threw himself into a comparative project with me (Grabosky and Braithwaite, 1986; Braithwaite and Grabosky, 1985). A greater contrast with the international influence of Ted Gurr's work with Peter could not be imagined. Ours was a comparative study of the regulatory strategies of all of Australia's most important business regulatory agencies, 103 of them. Again it was a path-breaking comparativism of unprecedented breadth that I would say Peter led. No one had ever compared the patterns of regulation of all the major agencies in one country. Peter had chosen his coauthor less wisely on this occasion, however. Virtually no one read or cited these books during more than the first decade of their existence. Oxford University Press (Australia) published Of Manners Gentle: Enforcement Strategies of Australian Business Regulatory Agencies (Grabosky and Braithwaite, 1986). Oxford (UK) ordered 66 copies for distribution across all of the UK and Europe! Few were interested internationally, Oxford thought, in a book with Australia in the title, even if it attempted a kind of comparativism that had never been done in any other country. There was in those days no discernible academic field of regulatory studies that created a market for the book.

Peter and I believed, nevertheless, that the social sciences could benefit from the building of such a field in a comparative fashion. We persisted in this forlorn belief, organising a national conference attended by a who's who of the most important and analytic leaders of Australia's regulatory agencies of 1991. These heads of our premier agencies produced excellent reflective written papers comparing their different approaches to regulatory strategy. Again, this endeavour was a flop. Attendance was poor, media interest was assiduously cultivated, but practically non-existent, and the book that was produced (Grabosky and Braithwaite, 1993) was purchased and cited by almost no one. It was remaindered in record time.

Peter spent a period on study leave from the Australian Institute of Criminology (where he had become Director of Research) at the Urban Research Unit of the Australian National University. During this time he 
wrote Smart Regulation with Neil Gunningham and Darren Sinclair (Gunningham, Grabosky and Sinclair, 1998). The new switch of co-authors allowed Peter this time to produce another book that became, almost instantly, a highly cited classic of regulatory studies. Gunningham and Grabosky became founding members of the Regulatory Institutions Network (today the School of Regulation and Global Governance (RegNet)) which Valerie Braithwaite and I established at the Australian National University in 2000. Darren Sinclair later joined his co-authors as another amazingly productive member of the RegNet faculty. In the wake of the success of Smart Regulation, northern hemisphere scholars began to discover our 1986 comparative Australian book, which had been ignored for 12 years by then.

Peter has by now spent as many years researching and writing at RegNet as the 18 years he spent at the Australian Institute of Criminology. In both institutions, he managed to help non-academic staff who had no training in criminology at the time to become world-renowned criminologists: Heather Strang, who was a librarian at the Australian Institute of Criminology, and Julie Ayling, who was a legal research assistant at RegNet. He became an institution-builder in creating the bourgeoning new twenty-first century field of regulatory studies, with formidable leadership from all over Australia. He also continued to be a leader in consolidating criminology as President of the Australian and New Zealand Society of Criminology and becoming a mentor to the founders of the Asian Criminological Society (among them Lennon Chang). For 10 years he was also a key member of the Campbell Collaboration Crime and Justice Coordinating Group and much more. The brilliance of his work was recognised in various international prizes.

To summarise this institutional contribution, Peter Grabosky was one of the great consolidators of the discipline of criminology in Australia and New Zealand. He helped criminology to take off across Asia. Yes, this book shows he made particularly strong contributions to the study of policing, but there was actually no sub-field of criminology - from violence to victimology to vice to vilification - that was untouched by Peter's research. He was internationally renowned as a criminologist for the breadth as well as the depth of his research. He was foundational to Australian leadership in institutionalising the field of regulatory studies as a central interdisciplinary topic of study across all the social sciences alongside many other great RegNet scholars. He was the mainstay of the germinal team of social scientists Ted Gurr led in developing the sophistication of interscalar comparative method not only in criminology but as a model for all the social sciences. Finally, he was an early mover in building certain sub-fields of criminology and regulatory studies. Cybersecurity was one of these, as the chapters in this book by Chang, Dupont and Urbas so ably show. Another consistently constructed theme that Grabosky made important across the social sciences is regulation by third parties that sit between the state and the regulatee, between police and citizens for example, and meta-regulation (regulated self-regulation or co-regulation). We see the latter themes in the chapters 
by Adrian and Lorraine Cherney, Ayling, Wood, Brewer, Lindley, Holder and Chang.

These more specific themes have been developed with profound impact in Peter Grabosky's research as the chapters of this book document so well. No sub-field of criminology today is fuelling growth in undergraduate enrolments in criminology more than cybersecurity. In our College of Asia and the Pacific at the Australian National University it is also fuelling enrolments in international relations, politics and national security studies. One of the big changes occurring in criminology today is a theoretical blurring of the distinction between crime and war, as war results in the criminalisation of states, for example. Grabosky (1989) was one of the early pioneers of the study of state crime. Cyberwar and cyberespionage are important parts of cybercrime today. I would go so far as to say that in contemporary conditions it makes little sense for the most powerful states to fire missiles at each other, so we have seen a historical movement from hot war, to cold war fought through proxies in weak states as the dominant form of militarised competition between major powers, and now moving to the era of cyberwar as the dominant modality of war that major powers consider deploying against each other. Peter was certainly more visionary than me on cybercrime. I remember arguing with Peter as we toured South Australian wineries during the 1979 ANZSOC conference that we were devoting too much attention to computer crime because only large organisations could afford to own a computer; so why not allow them to focus on defending themselves so we can focus on corporate crimes that victimise the powerless!

Julie Ayling's chapter is one vivid illustration of how and why the survival of our planet is quite unlikely without large investments in meta-regulation. Environmental activists were usually rather gloomy when international framework agreements such as the 1987 Montreal Protocol on ozone-depleting substances and the 1997 Kyoto Protocol on climate change were signed. They were cynical that these were purely symbolic agreements without enforcement teeth. Important states such as China that changed their behaviour greatly to implement these initially vague framework agreements have moved forward under the pressure of meta-regulatory dynamics. This is not to say that the movement has been sufficient to save us, merely that the moves have been of great importance, saving hundreds of thousands of lives in the case of the Montreal Protocol. As some major states moved on many originally vague framework agreements, the agreements were meta-regulated to gradually attain more specificity of content over time.

Peter Grabosky's accomplishments seem institutional but in fact were enacted in unusually interpersonal ways. Peter built intellectual engagement on a foundation of exceptional hospitality. Especially if they came from Japan, or somewhere else in Asia, visitors during these past 36 years when Peter lived in Canberra would be treated to large dollops of meat, with the patient endurance of his vegetarian partner Bronwyn McNaughton. Valerie Braithwaite and I are far from alone among Peter's colleagues and students in saying we have a great 
love for Peter, his kindness, and his intellectual hospitality. On the negative side, the largeness of those dollops of meat mean most of us co-authors will live shorter lives than had we never met Peter Grabosky. After sleeping in, amidst mutual recriminations over being kept awake by each other's alleged snoring, Peter and I would often be running late for our first fieldwork interview. Then Peter would insist on picking up an Australian meat pie each so we would not miss our meaty start to the day. Young people also identified with Peter because he lived such a well-rounded life in the way he indulged not only his intellectual and collegial passions but also his love of music, especially Chicago blues. Overly late nights in bars in Chicago, Osaka, Sydney and Taipei made for richer lives, even if shorter, especially for those who could not match Peter's passion for being up early in the morning to compensate with a long run.

There is evidence in this book of the way that Peter's collegiality and his wide reading has infected the intellectual imaginations of his collaborators. Few scholars read across such a range, or approach Peter Grabosky's literacy in international politics and society. For students, it was always hard to emerge from his office without being piled up with tomes that Peter felt would benefit them. He also created opportunities for many young scholars by being a 'rainmaker' who raised more funding for the research of younger scholars than for his own. The sophistication and nuance of those younger researchers is the feast of excellent scholarship in the Grabosky tradition on display in this book. This, even though most of the body of work of these authors, like Grabosky's own work, is not in the core of the Grabosky tradition. The book really gives a good feel for that core of the Grabosky oeuvre.

While Peter has won various international awards that mark his core criminological research distinction, this volume captures something of Peter's interdisciplinary scholarly imagination, his breadth and his sophistication, his focus on the building blocks for constructing new methods and new fields of study that transcend intellectual silos.

All the contributors to this volume are former ANU students or younger colleagues and co-authors of Peter Grabosky. Some of them now are very senior. This is the right way to celebrate the rich contributions of Peter Grabosky because he was always such a generous spirit to younger scholars he mentored. The students of all the greatest scholars collectively produce more than their mentor, as this volume evocatively demonstrates for Peter's progeny. Speaking personally, I am so proud of them getting together to honour Peter in this way under the leadership of Lennon Chang and Russell Brewer. At the same time, I do believe that distinguished older scholars such as Ted Gurr might wish that they too could join in to pay homage to how much they learnt sitting at the feet of the younger Peter Grabosky.

John Braithwaite

Distinguished Professor

School of Regulation and Global Governance Australian National University 


\section{References}

Braithwaite, J. and Grabosky, P.N. (1985) Occupational Health and Safety Enforcement in Australia. Canberra: Australian Institute of Criminology.

Grabosky, P.N. (1977) Sydney in Ferment: Crime, Dissent and Official Reaction, 1788 to 1973. Canberra: Australia National University Press.

Grabosky, P.N. (1989) Wayward Governance: Illegality and its Control in the Public Sector. Canberra: Australian Institute of Criminology.

Grabosky, P.N. and Braithwaite, J. (1986) Of Manners Gentle: Enforcement Strategies of Australian Business Regulatory Agencies. Melbourne: Oxford University Press.

Grabosky, P.N. and Braithwaite, J. (1993) Business Regulation and Australia's Future. Canberra: Australian Institute of Criminology.

Gunningham, N., Grabosky, P. and Sinclair, D. (1998) Smart Regulation: Designing Environmental Policy. Oxford: Oxford University Press.

Gurr, T.R. (1970) Why Men Rebel. Princeton. New Jersey: Princeton University Press.

Gurr, T.R, Grabosky, P.N., and Hula, R.C., with Peirce, D., Persson, L. and Sperlings, S. (1977) The Politics of Crime and Conflict: A Comparative History of Four Cities. Beverly Hills: Sage.

Stohl, M., Lichbach, M.I. and Grabosky, P.N. (eds) (2017) States and Peoples in Conflict: Transformations of Conflict Studies. New York: Routledge. 


\section{Acknowledgements}

The editors would like to thank a number of individuals who were instrumental in this volume coming to fruition. First and foremost, we are grateful to Morgen Sayer for her research and administrative assistance. We also thank Silvana Bevilacqua for lending her illustrative talents in the creation of various diagrams throughout this book. We further acknowledge both the contributing authors and anonymous reviewers for their timely responses and inputs. Finally, we thank the editorial team at Routledge for their encouragement and support from start to finish. 
Part I

Setting the scene 


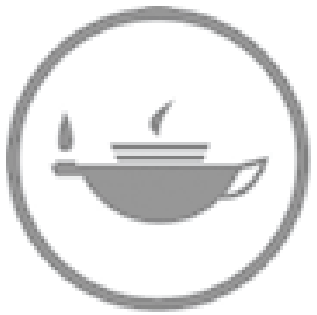

Taylor \& Francis Taylor \& Francis Group

http://taylorandfrancis.com 


\title{
Chapter I
}

\section{Peter Grabosky}

\section{At the interface of criminal justice and regulation}

\author{
Russell Brewer and Lennon Y.C. Chang
}

This edited volume celebrates the significant contributions of Peter Grabosky to the field of Criminology, and in particular, his work developing and adapting regulatory theory to the study of policing and security. Over the past three decades, his path-breaking theoretical and empirical research has contributed to a burgeoning literature on the myriad ways regulatory systems drive state and non-state interactions in an effort to control crime. This collection of essays showcase Grabosky's pioneering treatment of key regulatory concepts as they relate to such interactions, and illustrate how his work has been instrumental in shaping contemporary scholarship and practice around the governance of security.

\section{Introduction}

Criminologists have, for decades now, acknowledged a significant transformation in the organisation of policing and security - notably through the emergence of pluralistic forms of crime control (e.g. Grabosky, 1992, 1995b, 2010; Bayley and Shearing, 2001; Fleming and Wood, 2006; Brodeur, 2010). No longer does the state retain a monopoly over the provision of policing services (Bayley and Shearing, 2001). Rather, the authorisation and delivery of security have become shaped by complex networks that integrate various state (or public) actors (e.g. police, intelligence agencies, regulators) with a diverse range of non-state (or private) actors (e.g. business, organisations and associations, community groups, private citizens). Considerable research has explored the convergence of such varied actors within a multiplicity of crime control contexts (e.g. Dupont, 2004; Cherney, O'Reilly and Grabosky, 2006a, 2006b; Fleming and Wood, 2006; Wood and Dupont, 2006). One important strand of research emerging from this literature has centred on regulatory systems. These very dimensions have been subject to considerable theoretical development and empirical specification by Grabosky - providing detailed insights into the complex regulatory systems and contexts within which these myriad actors must cohabitate. 
In this chapter, we review key theoretical developments within criminology pertaining to the evolution of crime control within the modern state, and trace Grabosky's key contributions to this literature. In particular, we draw out several concepts central to his work that explain the complex interplay between state, and non-state actors within regulatory systems. This includes foundational theorising around the delivery of security in the modern state and the emergence of 'co-production' in crime control contexts, as well as his significant conceptual development and empirical explorations of statecentric, private-centric, and hybrid forms of regulation. Considered together, this work elucidates the key roles of both state and non-state actors, their capacities and regulatory opportunities available.

\section{The transformation of crime control within the modern state}

To fully appreciate the complexity of intertwined involvements of state and non-state actors in contemporary policing and crime control, one must first give conceptual consideration to how the proliferation of non-state orderings within the modern state have reshaped the delivery of security in all but a handful of jurisdictions where the state has aggressively maintained its primacy. The gradual ascendency of neoliberal ideals as the predominant economic and political paradigm has brought with it widespread privatisation, marketisation, and increasingly dispersed forms of governance. Within criminal justice contexts, the state's longstanding role as 'guarantor of security' (Johnston and Shearing 2003, pp. 32) was also widely regarded to be substantially affected by these broader transformations, and supplanted by emergent public-private orderings (Bayley and Shearing, 1996; Grabosky, 1992, 1995b; Cherney, O'Reilly and Grabosky, 2006b). Notably, this process of 'multilateralisation' (Bayley and Shearing, 2001) has occurred in relation to the provision of crime control - with many policing or security-related roles becoming either commercialised or otherwise devolved to a range of non-state actors, and thus establishing broader networks of social control (Chang, Zhong and Grabosky, 2016; Brewer, 2017; Cherney, O’Reilly and Grabosky, 2006b).

The confluence of circumstances that have led to these profound changes in the way policing is delivered, and crime is controlled are numerous and interwoven. Some, like Bayley and Shearing (1996, 2001), contend that this trend is merely reflective of parallel shifts in governance more broadly occurring within the modern state itself: a product of fledgling economies in 1970s, the emergence of mass private property (see Shearing and Stenning, 1983; Kempa, 2004), as well as the decline of the Keynesian welfare state (see further, Newburn, 2001; Reiner, 2010). Others argue that the concurrent rise of what Beck (1992) terms a 'risk society' has also had a lasting impact on the ways criminal justice policy is conceived, and institutions operate. Here, it is suggested that risk management has emerged as a core technology that 
provides a 'systematic way of dealing with hazards and insecurities induced and introduced by modernization' (Beck, 1992, p. 21). This has led to a move away from more traditional conceptions of the state (and in particular, the police) as 'crime fighters' engaged in episodic 'bandit-chasing', toward one that emphasises risk mitigation and crime control as being the key objective (Buerger and Mazerolle, 1998). These developments have also been driven by significant advancements in computing, communication and surveillance technologies in recent decades, which has dramatically increased the quantity and quality of information available to state and non-state actors alike (Dupont, 2004; Brewer, 2017). Accordingly, policing scholars characterise the complexion of modern policing and security as more than a straightforward devolution onto subordinate orderings, but instead embody a blurring of roles and capacities into a risk-based technologically-facilitated exercise constructed to respond to and control crime (Johnston, 2000; Bayley and Shearing, 2001; Waring and Weisburd, 2002; Dupont, 2004; Hoogenboom, 2010).

This fulfilment of the exercise has created a pluralised crime control landscape comprising myriad state and non-state actors - cooperating and competing with one another in pursuit of internal and external objectives. Dupont (2004) notes that the inherent uncertainty attached to the fragmentation of security responsibilities has compelled involved actors to seek order by reaching out and coordinating their efforts with other vested interests (although not necessarily all vested interests). This has led to the opening of new lines of communication, the development of previously untapped social connections and the creation of alliances in pursuit of ameliorating crime problems. The shared public-private models that have emerged as a consequence of these developments are both expansive and multifaceted, and have produced a labyrinthine network of security provision arrangements comprising a host of state and non-state actors (see further, Brewer, 2017). It is within this pluralised context that Grabosky's principal theoretical and empirical contributions are made.

\section{Enabling crime control through regulation: toward a three-dimensional pyramid}

Scholars have, for some time now, studied the role of the state within this transformed landscape and, in particular, explored regulatory action within criminal justice contexts through a state-centric lens. Some of Grabosky's most important contributions are located within this literature, explicating the myriad ways that state institutions can use regulatory levers to co-produce and/or form alliances with other non-state orderings in pursuit of crime control outcomes (e.g. Grabosky, 1995a, 1995b, 1996). That is, the state may implement or enforce policies designed to persuade external parties to address crime problems through the provision of educational programmes, training opportunities, additional resources or other incentives. The state may further 
seek to induce private action by attaching stipulations to commercial agreements made with external parties. The state may also take more coercive action to compel external actors to implement practices related to crime control through the threat of financial penalty or legal sanction.

Grabosky (2010: 96) stresses the diversity of state action within such crime control settings, articulating that the role of state institutions, and particularly law enforcement has become one of:

monitoring the overall spaces in which they [non-state actors] operate, broadly defined, and one of 'fine tuning': manipulating incentives, accrediting private competencies and auditing third-party performance in order to facilitate the constructive contributions of non-government interests.

However, as Moore and Alpert (1993) point out, simply manipulating these conditions will not always produce desired outcomes. Using a community policing example, they argue that successful police engagement with community-based processes will also necessitate the 'development of strong relationships with institutions and individuals in the community' (Moore and Alpert, 1993: 112) - achieved only through sustained dialogue and interaction with non-state actors, which only then provides an adequate appreciation for the problems identified by the community at large. Elsewhere, Brewer (2014) also reiterates the importance of developing strong connections in the pursuit of co-productive crime control arrangements between state and non-state actors.

Accordingly, it is through a process of building robust relationships, alongside the careful use of purchasing power, incentives and regulatory levers, that state actors are able to transform 'the marketplace' in such a way that market outcomes fulfil a public good (Osborne and Gaebler, 1992: 280). As a means of affecting such transformation and harnessing the crime control capacities of non-state actors, Grabosky (1995b, 1996) identifies the range of basic 'forms' by which state activity can be shared or devolved. These forms, arranged from least coercive to most, include the provision of capacity building opportunities, offering incentives, the conferral of entitlements, the co-optation of external interests, record keeping and disclosure requirements, a required private interface, and conscription (see Table 1.1).

Grabosky (2010) notes that a state actor need not necessarily be bound by or rely upon a single regulatory form. Rather, they may elect to employ a variety of approaches - applying different forms to different actors, in different contexts, and even adopting a sliding scale for a single participant. This idea is consistent with findings of other prominent regulatory scholars, who have long touted the benefits of using such 'mixed' approaches (see Bardach and Kagan, 1982; Ayres and Braithwaite, 1992; Sparrow, 2000; amongst others). Elaborating on this point, Cherney (2008: 636) suggests that having such 


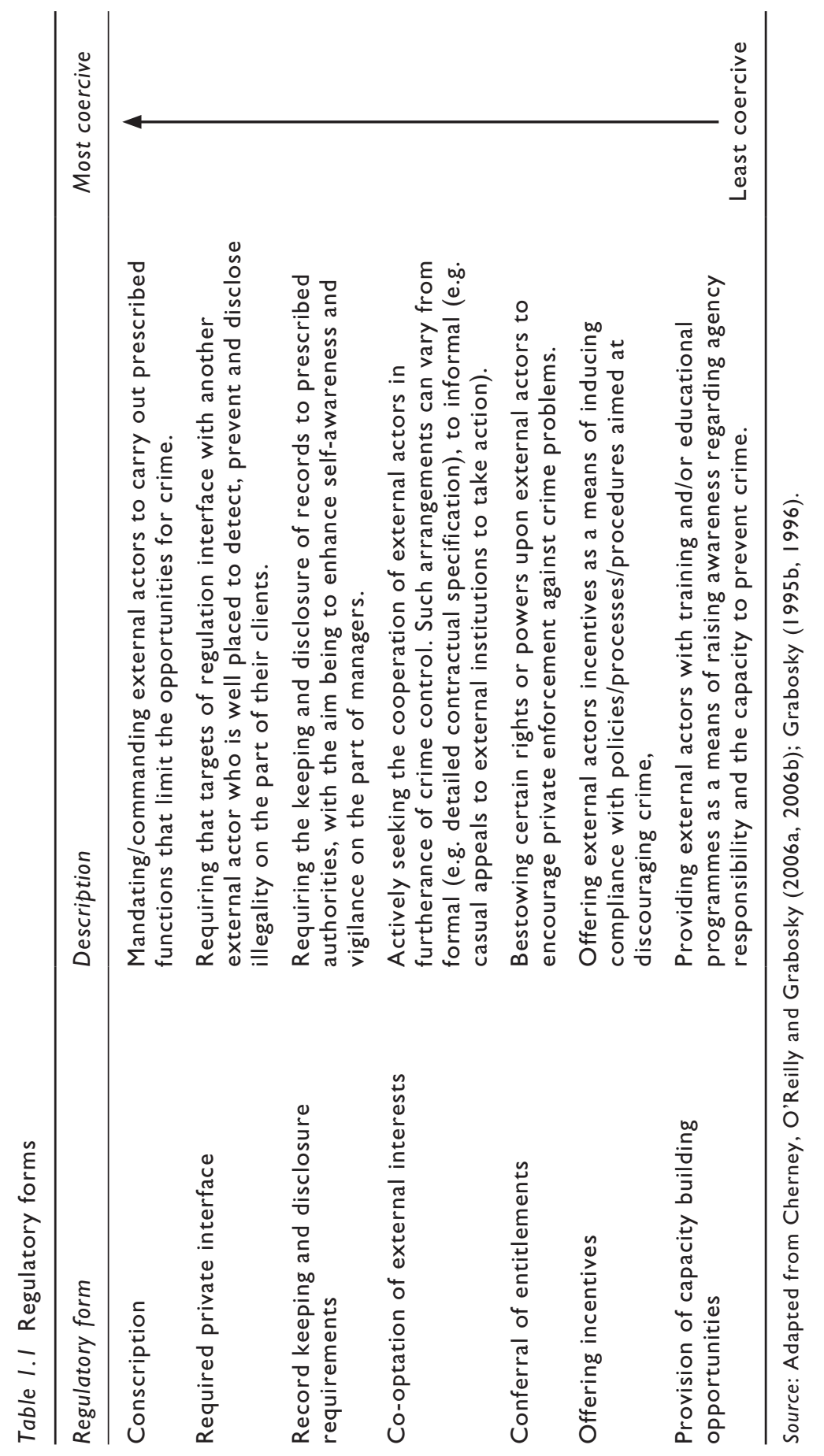


flexibility in approach provides targeting bodies the 'ability to escalate [and de-escalate] their responses' according to the successes or failures of the specific techniques aimed at compelling non-state actors to mobilise in furtherance of crime control outcomes.

Underpinning the scholarly debates surrounding the application of such 'mixed' approaches lies the concept of 'responsive regulation' (Ayres and Braithwaite, 1992). Responsive regulation aims to achieve regulatory outcomes by combining gentle persuasion with big sticks, or, put another way, through negotiated compliance and, if needed, the application of sanctions. Braithwaite (2000) argues that flexibility is the key to the delivery of responsive regulation, so that it can be adapted and scaled to suit the regulatory context (i.e. to address specific problems, different actors, or environments). Where previous regulatory narratives have favoured the more traditional command and control styles, responsive regulation emphasises efficiency and effectiveness, as well as the realisation of outcomes through decentralised and at-a-distance kinds of state regulation. Responsive regulation therefore seeks to promote an internal capacity for self-regulation by nonstate actors, whilst also fomenting a commitment to assert control over relevant systems in ways that are aligned with regulatory goals (Parker, 2002). Accordingly, having on hand a robust repertoire of strategies (i.e. a mixed approach) is fundamental to regulatory efforts aimed at harnessing the crime control capacities of non-state actors. The state cannot rely on only one regulatory form or instrument to affect desired outcomes, and instead necessitates 'a layered set of structures that [are] able to initiate cooperation in crime reduction based on the willingness and competency of a third-party to take action against crime' (Cherney, 2008: 639).

This is not to say that crime control activities undertaken by private actors are exclusively undertaken at the behest of the state. Rather, Grabosky and colleagues (i.e. Grabosky, 1997, 2010, 2013; Gunningham and Grabosky, 1998) recognised that the state is not necessarily always in the best position to direct regulatory outcomes, and that various actors external to the state's regulatory apparatus (e.g. the private sector or even external third parties) can also wield tremendous power within regulatory systems. In particular, they noted that private sector actors routinely self-regulate their activities - either entirely voluntarily, or as a consequence of direct or indirect involvement from the state. We can see examples of self-regulation across numerous critical infrastructure industries, including the financial and telecommunication sectors, who in an effort to reduce cybercrime comply with mandatory and voluntary reporting schemes, but also share information as a means to prevent potential losses (Chang, 2012; Chang and Grabosky, 2017). Furthermore, Grabosky and colleagues (Grabosky 1997, 2017; Gunningham and Grabosky, 1998) acknowledged the potentially significant influence of external third parties (either commercial or non-commercial interests) as regulatory actors. For example, in cases where the requisite security of safety standards are not 
met, insurers might refuse to insure against loss, industry associations may choose to withdraw support or accreditation, retailers and importers concerned with their brand image may switch to otherwise compliant suppliers, or consumer groups (or even influential individuals) may generate enough publicity to affect market preferences and drive regulatory outcomes (Grabosky, 2013).

Recognition of this pluralistic landscape led Grabosky and colleagues (Grabosky, 1997, 2010; Gunningham and Grabosky, 1998) to expand upon prevailing state-centric models of regulatory enforcement and provide enhanced understandings of the diversity of regulatory instruments available to all actors involved in such systems. To frame this work, they conceived of a three-dimensional regulatory pyramid that addresses perceived shortcomings of previous state-centric models (Grabosky, 1997), and permits the mapping of myriad regulatory instruments or institutions, be they state, private or hybrid.

This model is predicated on the regulatory pyramid, first proposed by Ayres and Braithwaite (1992) who argued that effective regulation necessitates the tailored use of a graduated scale of regulatory instruments as a means of achieving regulatory goals, which include, at the bottom (and therefore most frequent), efforts at persuasion, moving upwards toward issuing of warning letters, civil penalties, criminal penalties and, at the top, the suspension or revocation of licences. They suggested that although each instrument can stand alone, the combination of the instruments could be more effective. In augmenting this work, the three-dimensional pyramid combines elements of state, self-regulatory or third party activity and is comprised of three faces: first party (the state as the regulator; i.e. Ayres-Braithwaite original regulatory pyramid), second party (the regulated entity as a self-regulator), and third parties (both commercial and non-commercial interests) (see Figure 1.1). Grabosky $(1997,2010)$ notes that, theoretically, any regulatory action can be precisely mapped on or within the pyramid - the horizontal location reflecting the institutional (or inter-institutional) sponsor(s) of said action, and the vertical location reflecting the degree of coerciveness deployed (a higher location denoting the use of more coercive regulatory instruments) (Grabosky, 1997, 2010).

It is not difficult to envisage the application of the three-dimensional pyramid within crime control settings. Informal institutions or groups engaging in less coercive forms of social control will be represented at the base of the pyramid, located some distance away from the more formal instruments deployed along the state facade (Grabosky, 2010). Elsewhere, the frequent use by second and third parties of private civil remedies for crime control purposes (see Mazerolle and Ransley, 2005), or the likes of anti-social behaviour orders in the UK will be also be located near the apex of the pyramid (Grabosky, 2010). 


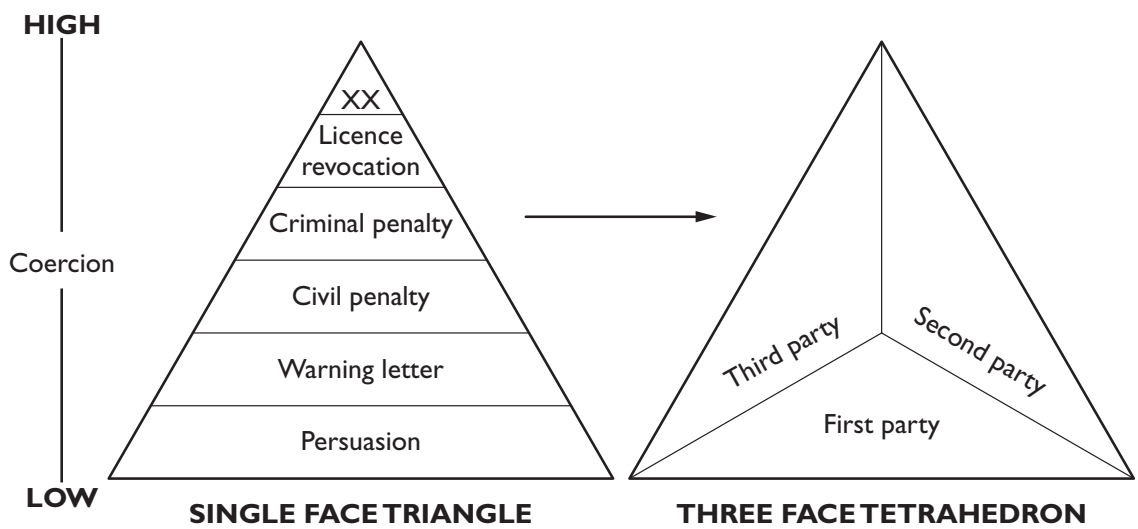

Figure I.I The three-dimensional pyramid.

Source: adapted from Grabosky, 2010.

\section{Moving forward: this volume and beyond}

In seeking to push this work further, Grabosky (2010: 80-81) laments that 'current scholarship might not have attained the sophistication in conceptualisation and measurement' to allow for the formal representation of such regulatory systems - especially comparatively. Rather, he suggests that further empirical expansion of his original concepts is warranted, going so far as to suggest that

the next generation of regulatory scholars may include those who might wish to undertake more precise description or modelling of regulatory systems ... permit[ting] a degree of hypothesis testing and theory building that has thus far been largely absent from the literature on regulation.

Along these lines, Grabosky's important conceptual contributions are explored in this volume and developed further through empirical studies presented by this next generation of scholars. Uniquely, the editors sought contributions from individuals who had previously enjoyed a close personal connection with Peter Grabosky - each having had the opportunity to work directly with him at The Australian National University as they established their research careers, and embarked upon their own innovative and distinct programmes of research.

The collection of theoretical and empirical work will be explored in this book in four parts. Part I sets the scene. In this first chapter co-authored by the editors, we introduce and depict, conceptually, the roles and regulatory systems binding state and non-state actors in the authorisation and delivery of security. It is here where an intellectual portrait of Peter Grabosky's contributions to this scholarship is also introduced. 
Part II of this this book explores the varied role of the state as a sponsor of regulatory activity through empirical studies undertaken by contributors.

In Chapter 2, Lorraine and Adrian Cherney outline how Grabosky's pathbreaking work can serve as a toolkit for policy-makers to better understand the task of regulation and effective compliance co-production. This is accomplished through an analysis of drug enforcement and gambling regulation, which draws out the multiplicity of ways in which states can enlist the capacities of third parties in the pursuit of various crime control objectives. Through the cases presented, they interrogate the ways that such regulatory systems operate, and provide readers with enhanced understandings of their form and function, as well as the risks associated with an increased reliance upon non-state actors in the pursuit of crime control objectives.

In Chapter 3, Julie Ayling studies the limits of state involvement in the enforcement and prevention of transnational environmental crime. She draws upon Grabosky's important work on meta-regulatory approaches to the governance of security as a means of suggesting a way forward for addressing this problem. In particular, she emphasises the need for carefully scripted interventions, including those that enrol and incentivise well-placed third parties who are otherwise disengaged in such activities. She theorises on the potential for further state-led meta-regulatory efforts within a chain of events and decisions that could induce private preventive or enforcement actions.

The discussion of state-sponsored approaches is wrapped up in Chapter 4, where Jennifer Wood examines how regulatory regimes might be re-aligned to improve the provision of state-provided services. Her chapter links to her previous work on regulation through 'enrolment', and explores recent initiatives designed at moving police beyond crime-based regulation toward the regulation of health and criminogenic risks. Her findings document an expanding horizon of institutional forms and relationships designed to minimise coercive regulation through punishment and incapacitation. Such developments, she argues, reveal the importance and increasing salience of Grabosky's ground-breaking schema of responsive regulation in threedimensional space.

Part III of this book examines second and third parties as sponsors of regulatory activity.

In Chapter 5, Robyn Holder looks past state-centric regulatory perspectives to explore the emergence of non-state actors within a domain of public prosecutions, where there has arguably been a weakening of state institutions. Here, she accepts Grabosky's invitation to further explore the democratisation of regulatory activity, and to look beyond that which is sponsored by the state. Her chapter examines the capacities of third parties to request, demand, press for and/or conduct a prosecution for wrongdoing in instances where the state is either unable or unwilling to take action. She shows that such actions may be undertaken at different levels, by individuals, or through collectives - and may involve collaborating with, or even co-opting public prosecution to take 
action. In this way, third parties, energised by a meld of private and public interests, can effectively serve as legal, social and political actors.

Building on these themes, Russell Brewer, in Chapter 6, looks at this private-centric narrative through an empirical study that demonstrates how non-state actors can ascend to become the most strategically positioned actors within a security network. By quantitatively mapping the extent to which state actors mobilise their connections to address crime problems on the waterfront, Brewer identifies key state, but also non-state 'brokers' that are capable of bridging structural barriers and modulating the flows of network resources. An associated qualitative component explores the driving forces, illustrating how non-state actors can be entrepreneurial in terms of elevating their structural positioning and reach across a network.

Moving further offshore in Chapter 7, Jade Lindley charts the assemblage of state and non-state actors, and their combined regulatory efforts involved in combatting maritime piracy. With her focus on the region off the Somali coast, she evaluates presiding legal and regulatory frameworks, as well as actor interactions and capacities to produce an original narrative depicting regulatory pluralism in action. Of particular interest, are her findings detailing the extent to which non-state actors (in this case private shipping interests) are capable of mobilising extensive, multi-state responses to successfully suppress criminal (and commercial) threats.

In Chapter 8, Gregor Urbas builds upon Grabosky's varied work exploring the regulatory responsibilities and capacities of commercial interests in online contexts. Here, Urbas elucidates the untapped potential for telecommunication companies to act as key information brokers - as both repositories and gatekeepers to data on user identities and activities. Through his detailed examination of the regulatory systems and environment driving commercial security practices in this domain, he develops a more nuanced understanding of both the nature and limits of commercial contributions towards state efforts aimed at detecting, enforcing and prosecuting cybercrime.

In Chapter 9 Lennon Chang examines the capacities and consequences of the participation of individual (private) Internet users in the investigation of criminal activities online. Traditional police resources are no longer sufficient to investigate crime in the digital age and manage cybersecurity. Building upon Grabosky's work on the role of non-state actors in the regulatory process and co-production of compliance, Chang discusses how democratisation of technology facilitates and empowers Internet citizens to become Internet vigilantes and become co-producers of security in the digital era. Drawing upon his past research on cyber crowdsourcing in the greater China region, Chang details types of Internet vigilantism, the characteristics of the Internet vigilantes, and the legal and ethical issues of citizen co-production of security in the digital era, an emerging but under-researched topic.

Part IV of this book seeks to move beyond the state- and private-centric systems explored thus far and chart new regulatory dimensions. 
In Chapter 10, Benoît Dupont presents an empirical study that explores a domain where strictly state-centric and private-centric regulatory systems have thus far failed - the Internet. Here, Dupont leverages Grabosky's earlier work on private regulation and modes of public-private exchange to examine the linkages of transnational state and non-state actors and initiatives constituting the 'global anti-cybercrime web', and to reveal the presence of a polycentric system of governance. His analysis undertakes to map these interactions, and in doing so offers important new insights about the composition and operation of such polycentric systems.

In the final chapter of this book, the editors draw together and summarise the key theoretical and empirical strands that have emerged through the essays presented in this volume. In doing so, they revisit Grabosky's academic contributions and its broader influence. They conclude by sketching directions for future research.

\section{References}

Ayres, I. and Braithwaite, J. (1992) Responsive regulation: Transcending the deregulation debate. Oxford: Oxford University Press.

Bardach, E. and Kagan, R.A. (1982) Going by the book: The problem of regulatory unreasonableness. Philadelphia: Temple University Press.

Bayley, D.H. and Shearing, C. (1996) 'The future of policing'. Law \& Society Review, 30(3): 585-606.

Bayley, D.H. and Shearing, C. (2001) The new structure of policing: Description, conceptualization, and research agenda. Washington, DC: National Institute of Justice, US Department of Justice.

Beck, U. (1992) Risk society. London: Sage.

Braithwaite, J. (2000) 'The new regulatory state and the transformation of criminology'. British Journal of Criminology, 40(2): 222-238.

Brewer, R. (2014) Policing the waterfront: Networks, partnerships, and the governance of port security. Oxford: Oxford University Press.

Brewer, R. (2017) 'Controlling crime through networks'. In P. Drahos (ed.), Regulation, institutions and networks. Canberra: ANU Press.

Brodeur, J.P. (2010) The policing web. New York: Oxford University Press.

Buerger, M.E. and Mazerolle, L. (1998) 'Third-party policing: A theoretical analysis of an emerging trend'. Justice Quarterly, 15(2): 301-327.

Chang, L.Y.C. (2012) Cybercrime in the Greater China Region: Regulatory responses and crime prevention across the Taiwan Strait. Cheltenham: Edward Elgar.

Chang, L.Y.C. and Grabosky, P. (2017) 'The governance of cyberspace'. In P. Drahos (ed.), Regulatory theory: Foundations and applications. Canberra: ANU Press.

Chang, L.Y.C., Zhong, Y. and Grabosky, P. (2016) 'Citizen co-production of cyber security: Self-Help, Vigilantes, and Cybercrime’. Regulation \& Governance, DOI: $10.1111 /$ rego.12125.

Cherney, A. (2008) 'Harnessing the crime control capacities of third parties'. Policing: An International Journal of Police Strategies E Management, 31(4): 631-647.

Cherney, A., O'Reilly, J. and Grabosky, P. (2006a) 'Networks and meta-regulation: Strategies aimed at governing illicit synthetic drugs'. Policing \& Society, 16(4): 370-385. 
Cherney, A., O’Reilly, J. and Grabosky, P. (2006b). 'The multilateralization of policing: The case of illicit synthetic drug control'. Police Practice and Research, 7(3): 177-194.

Dupont, B. (2004) 'Security in the age of networks'. Policing \& Society, 14(1): 76-91.

Fleming, J. and Wood, J. (2006) Fighting crime together: The challenges of policing and security networks. Sydney: UNSW Press.

Grabosky, P. (1992) 'Law enforcement and the citizen: Non-government participants in crime prevention and control'. Policing \& Society, 2(4): 249-271.

Grabosky, P. (1995a) 'Regulation by reward: On the use of incentives as regulatory instruments'. Law \& Policy, 17(3): 257-282.

Grabosky, P. (1995b) 'Using non-governmental resources to foster regulatory compliance'. Governance: An International Journal of Policy and Administration, 8(4): 527-550.

Grabosky, P. (1996) The future of crime control. Canberra: Australian Institute of Criminology.

Grabosky, P. (1997) 'Inside the pyramid: Towards a conceptual framework for the analysis of regulatory systems'. International Journal of the Sociology of Law, 25(3): 195-201.

Grabosky, P. (2010) 'On the interface of criminal justice and regulation'. In H. Quirk, T. Seddon and G. Smith (eds), Regulation and criminal justice: Innovations in policy and research. Cambridge: Cambridge University Press, pp. 72-100.

Grabosky, P. (2013) 'Beyond responsive regulation: The expanding role of non-state actors in the regulatory process'. Regulation and Governance, 7(1): 114-123.

Grabosky, P. (2017) 'Meta-regulation'. In P. Drahos (ed.), Regulatory theory: Foundations and applications. Canberra: ANU ePress, pp. 149-161.

Gunningham, N. and Grabosky, P. (1998) Smart regulation: Designing environmental policy. New York: Oxford University Press.

Hoogenboom, B. (2010) The governance of policing and security: Ironies, myths and paradoxes. London: Palgrave Macmillan.

Johnston, L. (2000) Policing Britain: Risk, security and governance. Essex: Longman.

Johnston, L. and Shearing, C. (2003) Governing security: Explorations in policing and justice. London: Routledge.

Kempa, M. (2004) 'Policing communal spaces: A reconfiguration of the "mass private property" hypothesis'. British Journal of Criminology, 44(4): 562-581.

Mazerolle, L. and Ransley, J. (2005) Third party policing. Cambridge: Cambridge University Press.

Moore, M.H. and Alpert, G.P. (1993) 'Measuring police performance in the new paradigm of policing'. In J. DiIulio Jr., G.P. Alpert, M.H. Moore, et al. (eds), Performance measures for the criminal justice system. NCJ 143505, Washington, DC: Bureau of Justice Statistics - Princeton University, pp. 1-176.

Newburn, T. (2001) 'The commodification of policing: Security networks in the late modern city'. Urban Studies, 38(5-6): 829-848.

Osborne, D. and Gaebler, T. (1992) Reinventing government: How the entrepreneurial spirit is transforming the public sector. New York: Addison-Wesley.

Parker, C. (2002) The open corporation: Effective self regulation and democracy. Cambridge: Cambridge University Press.

Reiner, R. (2010) The politics of the police. New York: Oxford University Press.

Shearing, C. and Stenning, P. (1983) 'Private security: Implications for social control'. Social Problems, 30(5): 493-506. 
Sparrow, M.K. (2000) The regulatory craft: Controlling risks, solving problems and managing compliance. Washington, DC: Brookings Institution Press.

Waring, E. and Weisburd, D. (2002) 'Editors' introduction'. In E. Waring and D. Weisburd (eds), Crime and Social Organization. New Brunswick, NJ: Transaction Publishers, pp. $\mathrm{xv}-\mathrm{xviii}$.

Wood, J. and Dupont, B. (2006) Democracy, society and the governance of security. Cambridge: Cambridge University Press. 


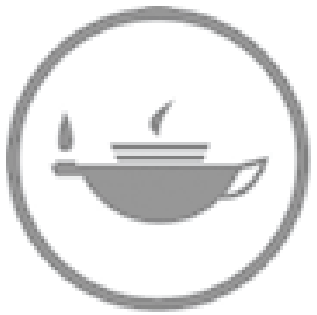

Taylor \& Francis Taylor \& Francis Group

http://taylorandfrancis.com 


\section{Peter Grabosky}

Ayres, I. and Braithwaite, J. (1992) Responsive regulation: Transcending the deregulation debate. Oxford: Oxford University Press.

Bardach, E. and Kagan, R.A. (1982) Going by the book: The problem of regulatory unreasonableness. Philadelphia: Temple University Press.

Bayley, D.H. and Shearing, C. (1996) The future of policing Law \& Society Review, 30(3): 585606.

Bayley, D.H. and Shearing, C. (2001) The new structure of policing: Description, conceptualization, and research agenda. Washington, DC: National Institute of Justice, US Department of Justice.

Beck, U. (1992) Risk society. London: Sage.

Braithwaite, J. (2000) The new regulatory state and the transformation of criminology $\square$ Bitish Journal of Criminology, 40(2): 222区38.

Brewer, R. (2014) Policing the waterfront: Networks, partnerships, and the governance of port security. Oxford: Oxford University Press.

Brewer, R. (2017) Dontrolling crime through networks Dn P. Drahos (ed.), Regulation, institutions and networks. Canberra: ANU Press.

Brodeur, J.P. (2010) The policing web. New York: Oxford University Press.

Buerger, M.E. and Mazerolle, L. (1998) Third-party policing: A theoretical analysis of an emerging trend $\square$ Justice Quarterly, 15(2): 301BD7.

Chang, L.Y.C. (2012) Cybercrime in the Greater China Region: Regulatory responses and crime prevention across the Taiwan Strait. Cheltenham: Edward Elgar.

Chang, L.Y.C. and Grabosky, P. (2017) The governance of cyberspace Dn P. Drahos (ed.), Regulatory theory: Foundations and applications. Canberra: ANU Press.

Chang, L.Y.C. , Zhong, Y. and Grabosky, P. (2016) ditizen co-production of cyber security: SelfHelp, Vigilantes, and Cybercrime $[$ Regulation \& Governance, DOI: 10.1111/rego.12125.

Cherney, A. (2008) Barnessing the crime control capacities of third parties $\square$ Policing: An International Journal of Police Strategies \& Management, 31(4): 631647.

Cherney, A. , OBeilly, J. and Grabosky, P. (2006a) Detworks and meta-regulation: Strategies aimed at governing illicit synthetic drugs Policing \& Society, 16(4): 370385.

14 Cherney, A. , OBeilly, J. and Grabosky, P. (2006b). The multilateralization of policing: The

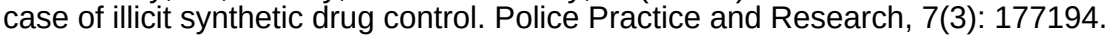

Dupont, B. (2004) Slecurity in the age of networks Policing \& Society, 14(1): 7691.

Fleming, J. and Wood, J. (2006) Fighting crime together: The challenges of policing and security networks. Sydney: UNSW Press.

Grabosky, P. (1992) Eaw enforcement and the citizen: Non-government participants in crime prevention and control $\square$ Policing \& Society, 2(4): 2492771.

Grabosky, P. (1995a) Begulation by reward: On the use of incentives as regulatory instruments $\square$ Law \& Policy, 17(3): 257282.

Grabosky, P. (1995b) Dsing non-governmental resources to foster regulatory compliance $\square$ Governance: An International Journal of Policy and Administration, 8(4): 527550.

Grabosky, P. (1996) The future of crime control. Canberra: Australian Institute of Criminology. Grabosky, P. (1997) Wiside the pyramid: Towards a conceptual framework for the analysis of regulatory systems $\square$ nternational Journal of the Sociology of Law, 25(3): 195201.

Grabosky, P. (2010) On the interface of criminal justice and regulation $D n$ H. Quirk, T. Seddon and G. Smith (eds), Regulation and criminal justice: Innovations in policy and research.

Cambridge: Cambridge University Press, pp. 72[000.

Grabosky, P. (2013) Beyond responsive regulation: The expanding role of non-state actors in the regulatory process Regulation and Governance, 7(1): 114T23.

Grabosky, P. (2017) Beta-regulationDn P. Drahos (ed.), Regulatory theory: Foundations and applications. Canberra: ANU ePress, pp. $149 \mathbb{1} 61$.

Gunningham, N. and Grabosky, P. (1998) Smart regulation: Designing environmental policy. New York: Oxford University Press.

Hoogenboom, B. (2010) The governance of policing and security: Ironies, myths and paradoxes. London: Palgrave Macmillan.

Johnston, L. (2000) Policing Britain: Risk, security and governance. Essex: Longman. Johnston, L. and Shearing, C. (2003) Governing security: Explorations in policing and justice. London: Routledge.

Kempa, M. (2004) Bolicing communal spaces: A reconfiguration of the mass private property $\square$ hypothesis British Journal of Criminology, 44(4): 562581.

Mazerolle, L. and Ransley, J. (2005) Third party policing. Cambridge: Cambridge University Press. 
Moore, M.H. and Alpert, G.P. (1993) Measuring police performance in the new paradigm of policing $\square n$ J. Dilulio Jr. , G.P. Alpert, M.H. Moore, et al. (eds), Performance measures for the criminal justice system. NCJ 143505, Washington, DC: Bureau of Justice Statistics Princeton University, pp. 1 II76.

Newburn, T. (2001) The commodification of policing: Security networks in the late modern city $\square$ Urban Studies, 38(56): 829848.

Osborne, D. and Gaebler, T. (1992) Reinventing government: How the entrepreneurial spirit is transforming the public sector. New York: Addison-Wesley.

Parker, C. (2002) The open corporation: Effective self regulation and democracy. Cambridge:

Cambridge University Press.

Reiner, R. (2010) The politics of the police. New York: Oxford University Press.

Shearing, C. and Stenning, P. (1983) Private security: Implications for social control $\square$ Social Problems, 30(5): 493506.

15 Sparrow, M.K. (2000) The regulatory craft: Controlling risks, solving problems and managing compliance. Washington, DC: Brookings Institution Press.

Waring, E. and Weisburd, D. (2002) Editors [introductionDn E. Waring and D. Weisburd (eds), Crime and Social Organization. New Brunswick, NJ: Transaction Publishers, pp. xvखviii.

Wood, J. and Dupont, B. (2006) Democracy, society and the governance of security.

Cambridge: Cambridge University Press.16

\section{Regulation beyond the state}

Australian Criminal Intelligence Commission (2016) Illicit Drug Data Report 2014파. Australian Criminal Intelligence Commission, Canberra.

Ayling, J. (2013) Barnessing third parties for transnational environmental crime prevention $\square$ Transnational Environmental Law, 2(2): 339362.

Ayling, J. and Grabosky, P. (2006) Bolicing by command: Enhancing law enforcement capacity through coercionLaw \& Policy, 28(4): 420443.

Ayres, I. and Braithwaite, J. (1992) Responsive regulation: Transcending the deregulation debate. New York: Oxford University Press.

Baldwin, R. , Cave, M. and Lodge, M. (2012) Understanding regulation: Theory, strategy, and practice. New York: Oxford University Press.

Bowman, D.M. and Hodge, G.A. (2008) Governing nanotechnology without government? Science \& Public Policy, 35(7): 475487.

Braithwaite, J. (2005) Markets in vice, markets in virtue. Australia: Federation Press.

30 Braithwaite, J. (2008) Regulatory capitalism: How it works, ideas for making it work better.

UK: Edward Elgar Publishing.

Braithwaite, J. , Healy, J. and Dwan, K. (2005) The governance of health safety and quality. Canberra: Commonwealth of Australia.

Brewer, R. (2015) The malleable character of brokerage and crime control: A study of policing, security and network entrepreneurialism on Melbourneß waterfront $\square$ Policing and Society, 27(7): 1 DO.

Brewer, R. and Grabosky, P. (2014) The unraveling of public security in the United States: The dark side of police-community co-productionDAmerican Journal of Criminal Justice, 39(1):

139 II54.

Crawford, A. (2006) Detworked governance and the post-regulatory state? Steering, rowing and anchoring the provision of policing and security TTheoretical Criminology, 10(4): 4494779.

Chang, L.Y.C. , Zhong, L.Y. and Grabosky, P.N. (2016) Ditizen co-production of cyber security: Self-help, vigilantes, and cybercrime $R$ Regulation and Governance, early view DOI:

10.1111/rego.12125.

Cherney, A. (2008) Barnessing the crime control capacities of third parties $\square$ Policing: An International Journal of Police Strategies \& Management, 31(4): 631647.

Cherney, A. , OBeilly, J. and Grabosky, P.N. (2005) The governance of illicit synthetic drugs. Hobart: National Drug Law Enforcement Research Fund.

Cherney, A. , OBeilly, J. and Grabosky, P. (2006) Detworks and meta-regulation: Strategies aimed at governing illicit synthetic drugs Policing \& Society, 16(4): 370385.

Degenhardt, L. , Sara, G. , McKetin, R. , Roxburgh, A. , Dobbins, T. , Farrell, M. and Hall, W.D. (2016a) Crystalline methamphetamine use and methamphetamine-related harms in Australia Drug and Alcohol Review, 36(2): 160170. 
Degenhardt, L. , Larney, S. , Chan, G. , Dobbins, T. , Weier, M. , Roxburgh, A. and McKetin, R. (2016b) Estimating the number of regular and dependent methamphetamine users in Australia, 20022014DMedical Journal of Australia, 204(4): 153.

Drew, J.M. (2011) Bolice responses to the methamphetamine problem: An analysis of the organizational and regulatory context $\square$ Police Quarterly, 14(2): 99ㅍ23.

Dupont, B. , Grabosky, P. and Shearing, C. (2003) The governance of security in weak and failing states $\square$ Criminal Justice, 3(4): 331349.

Ferris, J. , Devaney, M. , Mazerolle, L. and Sparkes-Carroll, M. (2016) Assessing the utility of Project STOP in reducing pseudoephedrine diversion to clandestine laboratories $\square$ rends and Issues in Crime and Criminal Justice, (509): 1.

Grabosky, P.N. (1992) Daw enforcement and the citizen: Non-governmental participants in crime prevention and control $\square$ Policing and Society: An International Journal, 2(4): 249071. Grabosky, P.N. (1994a) Beyond the regulatory state $\square$ Australian \& New Zealand Journal of Criminology, 27(2): 192 [97.

Grabosky, P.N. (1994b) Green markets: Environmental regulation by the private sector $\square$ aw \& Policy, 16(4): 419448.

Grabosky, P.N. (1995a) Using non-governmental resources to foster regulatory compliance $\square$ Governance, 8(4): 527550 .

Grabosky, P.N. (1995b) Begulation by reward: On the use of incentives as regulatory instruments Law \& Policy, 17(3): 257282.

Grabosky, P.N. (1995c) Counterproductive regulation Dnternational Journal of the Sociology of Law, 23(4): 347369.

31 Grabosky, P.N. (1997) Discussion paper: Inside the pyramid: Towards a conceptual framework for the analysis of regulatory systems $\square$ nternational Journal of the Sociology of Law, 25(3): 195201.

Grabosky, P. (2013) Beyond Responsive Regulation: The expanding role of non-state actors in the regulatory process $\square$ Regulation \& Governance, $7(1): 114 \mathbb{R} 3$.

Gunningham, N. , Phillipson, M. and Grabosky, P. (1999) Barnessing third parties as surrogate regulators: Achieving environmental outcomes by alternative means Business Strategy and the Environment, 8(4): 211 R24.

Haines, F. (2011) The paradox of regulation: What regulation can achieve and what it cannot. UK: Edward Elgar Publishing.

Head, B. and Ryan, N. (2004) Can co-governance work? Regional natural resource management in Queensland, AustraliaCSociety and Economy, 26(2B): 361382.

Hutter, B.M. (2011) Managing food safety and hygiene: Governance and regulation as risk management. UK: Edward Elgar Publishing.

Kraakman, R.H. (1986) Gatekeepers: The anatomy of a third-party enforcement strategy $\square$ Journal of Law, Economics, \& Organization, 2(1): 530․

Mazerolle, L. and Ransley, J. (2006) Third party policing. New York: Cambridge University Press.

Mazerolle, L. , McGuffog, I. , Ferris, J. and Chamlin, M.B. (2016) Dharmaceutical sales of pseudoephedrine: The impact of electronic tracking systems on methamphetamine crime incidents $\square$ Addiction, 112(3): 468474.

McMillen, J. (2009) Gambling policy and regulation in AustraliaDn J.F. Cosgrove and T.R. Klassen (eds), Casino state: Legalised gambling in Canada. Canada: University of Toronto Press.

Nielsen, V.L. and Parker, C. (2008) To what extent do third parties influence business compliance? Journal of Law and Society, 35(3): 309340.

Productivity Commission (1999) Australiaslgambling industries, inquiry report. Report no. 10, Canberra.

Productivity Commission (2010) Gambling inquiry. Report no. 50, Canberra.

Queensland Gaming Commission (2006) Queensland gaming commission annual report 200506. Queensland Gaming Commission, Brisbane.

Ransley, J. (2016) Bolicing through third parties: Increasing coercion or improving legitimacy? पh M. Deflem (ed.), The politics of policing: Between force and legitimacy. UK: Emerald Group Publishing Limited, pp. 4158.

Ransley, J. , Mazerolle, L. , Manning, M. , McGuffog, I. , Drew, J.M. and Webster, J. (2012) Reducing the methamphetamine problem in Australia: Evaluating innovative partnerships between police, pharmacies and other third parties. Monograph series no. 39, Canberra: National Drug Law Enforcement Research Fund.

Ritter, A. (2010) micit drugs policy through the lens of regulation $\square$ nternational Journal of Drug Policy, 21(4): 265270.

Scott, C. (2004) Begulation in the age of governance: The rise of the post regulatory state $\mathrm{nn} \mathrm{J}$. Jordana and D. Levi-Faur (eds), The politics of regulation: Institutions and regulatory reforms for 
the age of governance. UK: Edward Elgar Publishing, pp. 145ए74.

Scott, M. and Goldstein, H. (2005) Shifting and sharing responsibility for public safety problems, response guide no. 3. Viewed 20 August 2016, www.popcenter.org/responses/responsibility/.

Seddon, T. (2014) Drug policy and global regulatory capitalism: The case of new psychoactive substances (NPS) Dnternational Journal of Drug Policy, 25(5): 1019피․

32 Walker, C.K. (2016) Deoliberalism and the reform of regulation policy in the Australian trucking sector: Policy innovation or a repeat of known pitfalls? Policy Studies, 37(1): 7292. Webster, J. , Mazerolle, P. , Ransley, J. and Mazerolle, L. (2017) Disrupting domestic [e production: Deterring drug runners with a third-party policing intervention $\square$ Policing and Society, early view, 1ㅍ.

Williams, B.N. , Kang, S.C. and Johnson, J. (2016) (Co)-Contamination as the dark side of coproduction: Public value failures in co-production processes $\square$ Public Management Review, 18(5): 692717.

Wright, J.S. and Head, B. (2009) Beconsidering regulation and governance theory: A learning approach Law \& Policy, 31(2): $192 \mathbb{2 1 6 .}$

\section{Meta-regulating transnational environmental crime for better outcomes}

Ayling, J. (2013) Barnessing third parties for transnational environmental crime prevention $\square$ Transnational Environmental Law, 2(2): 339362.

Ayling, J. (2017a) Beducing demand for illicit wildlife products: Crafting a Whole-of-society $\square$ response $\mathrm{Cn}$ L. Elliott and W. Schaedla (eds), Handbook of Transnational Environmental Crime. Cheltenham UK: Edward Elgar, pp. 346368.

Ayling, J. (2017b) Transnational environmental crime: Meeting future challenges through networked regulatory innovations $\square n$ M. Hall , T. Wyatt, N. South, A. Nurse, G. Potter and J. Maher (eds), Greening criminology in the 21st century: Contemporary debates and future directions in the study of environmental harm. Abingdon, Oxon: Routledge, pp. 5976.

Ayling, J. , Grabosky, P. and Shearing, C. (2009) Lengthening the arm of the law: Enhancing police resources in the 21st century. New York: Cambridge University Press.

Ayres, I. and Braithwaite, J. (1992) Responsive regulation: Transcending the deregulation debate. New York: Oxford University Press.

Bayley, D. and Shearing, C. (2001) The new structure of policing: Description, conceptualization, and research agenda. Washington, DC: National Institute of Justice.

Braithwaite, J. (2005) Meta regulation of justice: RegNet occasional paper 4, viewed 20

September 2017,

https://s3.amazonaws.com/academia.edu.documents/40101412/.Meta_Regulation_2005.pdf?A

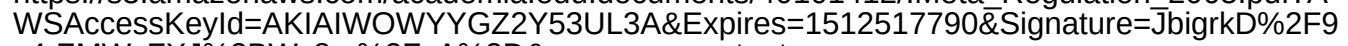
v4rZMWyFXJ\%2BWy8m\%2FyA\%3D\&response-content-

disposition=inline\%3B\%20filename\%3DMeta_Regulation_of_Justice.pdf.

Braithwaite, J. (2011) The essence of responsive regulation_University of British Columbia Law Review, 44(3): 475520.

Braithwaite, V. (2014) Defiance and motivational postures $\square$ n G. Bruinsma and D. Weisburd (eds), Encyclopedia of criminology and criminal justice. New York: Springer, pp. 915925. Brehm, J.W. (1966) A theory of psychological reactance. New York: Academic.

Brewer, R. (2014) Policing the waterfront: Networks, partnerships, and the governance of port security. Oxford: Oxford University Press.

Bullock, K. , Clarke, R.V. and Tilley, N. (2010) mtroductionDn K. Bullock, R.V. Clarke and N. Tilley (eds), Situational prevention of organised crime. Cullompton, Devon: Willan, pp. $1 \llbracket 6$. Challender, D. and MacMillan, D. (2016) Transnational environmental crime: More than an enforcement problem $\square \mathrm{n}$ L. Elliott and W. Schaedla (eds), Handbook of transnational environmental crime. Cheltenham UK: Edward Elgar, pp. 489498.

Chang, L.Y.C. , Zhong, L. and Grabosky, P. (2016) ditizen co-production of cyber security: Selfhelp, vigilantes, and cybercrime Regulation and Governance, early view DOI:

10.1111/rego.12125.

Cherney, A. , OBeilly, J. and Grabosky, P. (2006) Detworks and meta-regulation: Strategies aimed at governing illicit synthetic drugs $\square$ Policing and Society, 16(4): 370385.

Elliott, L. (2017) Criminal networks and illicit chains of custody $\square$ n L. Elliott and W. Schaedla (eds), Handbook of Transnational Environmental Crime. Cheltenham UK: Edward Elgar, pp. 2444.

Grabosky, P. (1995a) Dsing non-governmental resources to foster regulatory compliance $\square$ Governance, 8(4): 527550 . 
47 Grabosky, P. (1995b) Begulation by reward: On the use of incentives as regulatory instruments Law and Policy, 17(3): 257282.

Grabosky, P. (1995c) Counterproductive regulationDnternational Journal of the Sociology of Law, 23(4): 347369.

Grabosky, P. (1997) நnside the pyramid: Towards a conceptual framework for the analysis of regulatory systems $\square$ nternational Journal of the Sociology of Law, 25(3): 195201.

Grabosky, P. (2010) On the interface of criminal justice and regulation $\square \mathrm{n} H$. Quirk, T. Seddon and G. Smith (eds), Regulation and criminal justice: Innovations in policy and research.

Cambridge: Cambridge University Press, pp. 72[00.

Gunningham, N. and Grabosky, P. (1998) Smart regulation: Designing environmental policy. Oxford: Oxford University Press.

IUCN SSC Pangolin Specialist Group (2017) About,\viewed 2 October 2017, www.pangolinsg.org/about/.

Joh, E. (2006) Whe forgotten threat: Private policing and the state $\square$ ndiana Journal of Global Legal Studies, 13(2): 357389.

Loader, I. (2000) Blural policing and democratic governance $\square$ Social and Legal Studies, 9(3): 323345.

Merton, R. (1936) The unanticipated consequences of purposive social actionDAmerican Sociological Review, 1(6): 894904.

Nellemann, C. , Henriksen, R. , Raxter, P. , Ash, N. and Mrema, E. (2014) The environmental crime crisis: Threats to sustainable development from illegal exploitation and trade in wildlife and forest resourcesA UNEP Rapid Response Assessment, viewed 2 October 2017, unep.org/publications/.

Parker, C. and Braithwaite, J. (2003) BegulationDn P. Cane and M. Tushnet (eds), The Oxford handbook of legal studies. Oxford: Oxford University Press, pp. $119 \mathbb{4 4 5 .}$

Saydan, S. (2017) Driminality and costs: The human toll of transnational environmental crime $\square$ In L. Elliott and W. Schaedla (eds), Handbook of transnational environmental crime.

Cheltenham UK: Edward Elgar, pp. 88 $\mathbb{1 0 6}$.

Sherman, L. (1993) Defiance, deterrence, and irrelevance: A theory of the criminal sanction $\square$ Journal of Research in Crime and Delinquency, 30(4): 445473.

TRAFFIC (2014) E-commerce companies declare zero-tolerance towards illegal online wildlife trading, viewed 2 October 2017, www.traffic.org/home/2012/6/8/e-commerce-companiesdeclare-zero-tolerance-towards-illegal.html.

United for Wildlife (2016) What is the transport taskforce?, viewed 28 September 2017, www.unitedforwildlife.org/\#!/2016/03/what-is-the-transport-taskforce.

UNODC (2012) Wildlife and forest crime analytic toolkit. New York: United Nations.

UNODC (2016) World wildlife crime report: Trafficking in protected species 2016. New York: United Nations.

White, R. (2012) $\Delta G O$ engagement in environmental law enforcement: Critical reflections $\square$ Australasian Policing: A Journal of Professional Practice and Research, 4(1): 7[W.

Williams, A. , Parry-Jones, R. and Roe, D. (2016) The resource bites back: Entry-points for addressing corruption in wildlife crime, viewed 28 September 2017, www.u4.no/publications/theresource-bites-back-entry-points-for-addressing-corruption-in-wildlife-crime/.

48 Wyatt, T. (2013) Wildlife trafficking: A deconstruction of the crime, the victims, and the offender. Basingstoke: Palgrave Macmillan.

Wyatt, T. and Cao, A. (2015) Corruption and wildlife trafficking, viewed 28 September 2017, www.u4.no/publications/corruption-and-wildlife-trafficking/.

Zedner, L. (2006) Dolicing before and after the police: The historical antecedents of contemporary crime control[British Journal of Criminology, 46(1): 7896.

\section{Regulating through enrolment}

Ayres, I. and Braithwaite, J. (1992) Responsive regulation: Transcending the deregulation debate. New York: Oxford University Press.

Bailey, I. (2016) B.C. records 128 overdose deaths in November as coroner warns of Increasingly toxic đrug supply The Globe and Mail, 19 December 2016, viewed 22 September 2017, www.theglobeandmail.com/news/british-columbia/bc-records-128-overdose-deaths-innovember-highest-ever-recorded/article33364857/.

Baillargeon, J. , Binswanger, I.A. , Penn, J.V. , Williams, B.A. and Murray, O.J. (2009)

Bsychiatric disorders and repeat incarcerations: The revolving prison doorDAmerican Journal of Psychiatry, 166(1): 103ா09. 
Banta-Green, C.J. , Beletsky, L. , Schoeppe, J.A. , Coffin, P.O. and Kuszler, P.C. (2013) Bolice officers and paramedics Experiences with overdose and their knowledge and opinions of Washington StateBD Drug Overdose-Naloxone-Good Samaritan Law $\square$ Journal of Urban Health, 90(6): $1102 \mathbb{1 1 1 .}$

Bartkowiak-Thøon, I. and Asquith, N.L. (2012) Policing vulnerability. Annandale, NSW: Federation Press.

Bartkowiak-Thøon, I. and Asquith, N.L. (2017) Donceptual divides and practice synergies in law enforcement and public health: Some lessons from policing vulnerability in Australia Policing and Society, 27(3): 276288.

BBC News (2016) Erances first drug room for addicts to inject opens in Paris BBC News, 11 October 2016, viewed 25 October 2017, www.bbc.com/news/world-europe-37617360.

Bittner, E. (1967a) Bolice discretion in emergency apprehension of mentally ill persons $\square$ Social Problems, 14(3): 278292.

Bittner, E. (1967b) The police on skid-row: A study of peace keeping $\square$ American Sociological Review, 32(5): 699705.

Bittner, E. (1990) Aspects of police work. Boston: Northeastern University Press.

Blair, I. (2016) The police canモcontinue to pick up the pieces of Britainsmental health cuts $\square$ Guardian, 25 October 2016, viewed 25 September 2017,

www.theguardian.com/commentisfree/2016/oct/25/police-britain-mental-health-cuts-crisis.

63 Borum, R. , Deane, M.W. , Steadman, H.J. and Morrissey, J. (1998) Bolice perspectives on responding to mentally ill people in crisis: Perceptions of program effectiveness $\square$ Behavioral Sciences and the Law, 16(4): 393405.

Boston Healthcare for the Homeless Program (2017) Planned SPOT Center at 780 Albany Street, viewed 25 September 2017, www.bhchp.org/news/planned-spot-center-780-albanystreet\%5D.

Braithwaite, J. (2002) Restorative justice and responsive regulation. Oxford: Oxford University Press.

Braithwaite, J. (2003) What\$wrong with the sociology of punishment $\square$ Theoretical Criminology, 7(1): 528.

Braithwaite, J. (2008) Regulatory capitalism: How it works, ideas for making it work better.

Cheltenham, UK: Edward Elgar.

Braithwaite, J. (2014) Eybridity in the Canadian craft of criminology $[$ Canadian Journal of Criminology and Criminal Justice, 56(4): 399416.

Brauer, M.S. (2017) [nside a killer drug epidemic: A look at Americaßopioid crisis $\square$ New York Times, 6 January 2017, viewed 15 October 2017, www.nytimes.com/2017/01/06/us/opioidcrisis-epidemic.html? $r=0$.

Burris, S. , Blankenship, K.M. , Donoghoe, M. , Sherman, S. , Vernick, J.S. , Case, P. , Lazzarini, Z. and Koester, S. (2004) Addressing the risk environmentfor injection drug users: The mysterious case of the missing copपThe Milbank Quarterly, 82(1): 126156.

Burris, S. , Hancock, T. , Lin, V. and Herzog, A. (2007) Emerging strategies for healthy urban governance Journal of Urban Health, 84(S1): 154 I663.

Burris, S. , Wagenaar, A.C. , Swanson, J. , Ibrahim, J.K. , Wood, J. and Mello, M.M. (2010) Making the case for laws that improve health: A framework for public health law research $\square$ The Milbank Quarterly, 88(2): 169210.

Campbell, D. (2016) DHS mental health services failing young people, say psychiatrists $\square$ Guardian, 26 December 2016, viewed 25 September 2017,

www.theguardian.com/society/2016/dec/26/nhs-mental-health-services-failing-young-peoplesay-psychiatrists.

CBC News (2016) Toronto city councillors vote in favour of safe injection sites $\square$ CBC News, 14 July 2016, viewed 25 September 2017, www.cbc.ca/news/canada/toronto/safe-injection-sites1.3679058 .

Center for Behavioral Health Statistics and Quality (2015) Behavioral health trends in the United States: Results from the 2014 national survey on drug use and health, viewed 25 September 2017, www.samhsa.gov/data/sites/default/files/NSDUH-FRR1-2014/NSDUH-FRR1-2014.pdf.

Centers for Disease Control and Prevention (2016) Drug overdose death data, viewed 14 October 2017, www.cdc.gov/drugoverdose/data/statedeaths.html.

Charlier, J. (2015) Want to reduce drugs in your community? You might want to deflect instead of arrest $\square$ Police Chief, 82(9): 30311.

Cherney, A. , OBeilly, J. and Grabosky, P. (2006) Detworks and meta-regulation: Strategies aimed at governing illicit synthetic drugs $\square$ Policing and Society, 16(4): 370385.

City of Alexandria (2017) Detox services. Viewed 14 October 2017, www.alexandriava.gov/dchs/adultservices/default.aspx?id=50426.

64 CNBnews.net (2017) Since 2014 the Camden County Police Department has saved 260 overdose victims using Narcan $\square$ CNBnewsnet, 3 January 2017, viewed 25 September 2017, 
http://linkis.com/l1wjz.

Collins, S.E. , Nyrop, K. , Clifasefi, S.L. , Lonczak, H.S. and Daugaard, L. (2017) Seattleslaw enforcement assisted diversion (LEAD) program Evaluation and Program Planning, 64: 4956.

Cooper, H. , Moore, L. , Gruskin, S. and Krieger, N. (2005) The impact of a police drug crackdown on drug injectors [ability to practice harm reduction: A qualitative study $\square$ Social Science \& Medicine, 61(3): 673684.

Daly, P. (2016) D.S. should follow Canadaslead on heroin treatment $\square$ New York Times, 23 March 2016, viewed 25 September 2017, www.nytimes.com/2016/03/23/opinion/us-shouldfollow-canadas-lead-on-heroin-

treatment.html?action=click\&contentCollection=N.Y.\%20\%2F\%20Region\&module=RelatedCov erage\&region=Marginalia\&pgtype=article.

Davidson, H. (2016) mdigenous disadvantage getting worse in mental health and incarceration $\square$ Guardian, 16 November 2016, viewed 25 September 2017, www.theguardian.com/australianews/2016/nov/17/indigenous-disadvantage-mental-health-domestic-violence-incarceration. Davis, C.S. , Burris, S. , Kraut-Becher, J. , Lynch, K.G. and Metzger, D. (2005) Effects of an intensive street-level police intervention on syringe exchange program use in Philadelphia, $\mathrm{Pa} \square$ American Journal of Public Health, 95(2): 2332B6.

Davis, C.S. , Carr, D. , Southwell, J.K. and Beletsky, L. (2015) Engaging law enforcement in overdose reversal initiatives: Authorization and liability for Naloxone administration. American Journal of Public Health, 105(8): 1530 II537.

Department of Health and Human Services (2016) The opioid epidemic: By the numbers. Viewed 14 October 2017, www.hhs.gov/sites/default/files/Factsheet-opioids-061516.pdf. Ditton, P. (1999) Mental health and treatment of inmates and probations. Viewed 14 October 2017, www.bjs.gov/content/pub/pdf/mhtip.pdf.

Dodd, V. (2016) Bolice say they are becoming emergency mental health services $\square$ Guardian, 10 October 2016, viewed 14 October 2017, www.theguardian.com/uk-news/2016/oct/09/policeforces-mental-health-section-136.

Drug Enforcement Administration (2016) DEA issues Carfentanil warning to police and public. Viewed 25 September 2017, www.dea.gov/divisions/hq/2016/hq092216.shtml.

Durkin, E. (2016) DYC considers adding facilities for addicts to use drugs under medical supervision[New York Daily News, 28 September 2016, viewed 14 October 2017, www.nydailynews.com/news/politics/nyc-eyes-safe-sites-addicts-drugs-article-1.2810862. Epperson, M. (2016) Where police violence encounters mental illness $[$ New York Times, 13 January 2016, viewed 25 September 2017, www.nytimes.com/2016/01/13/opinion/where-policeviolence-encounters-mental-illness.html? $r=0$.

Evans, A. (2013) Bental healthsgreat gray area[Philadelphia Inquirer, 11 January 2013, viewed 14 October 2017, http://dbhids.org/news/mental-healths-great-gray-area-op-ed/. Foderaro, L.W. (2016) ThacaSlanti-heroin plan: Open a site to shoot heroin $\square$ New York Times, 22 March 2016, viewed 14 October 2017, www.nytimes.com/2016/03/23/nyregion/fightingheroin-ithaca-looks-to-injection-centers.html.

65 Fox, M. (2015) Drug overdose deaths hit alarming Whew record in U.S., CDC says $\square$ NBC News, 18 December 2015, viewed 25 September 2017, www.nbcnews.com/health/healthnews/drug-overdose-deaths-hit-new-record-u-s-cdc-says-n482746.

Franz, S. and Borum, R. (2011) Drisis intervention teams may prevent arrests of people with mental illnesses Police Practice and Research, 12(3): 265R72.

Gill, P. (2002) Bolicing and regulation: What is the difference?\$ocial and Legal Studies, 11(4): 523546.

Glauser, W. , Petch, J. and Tierney, M. (2016) Bospital policies put the lives of people who inject drugs at risk, say experts $\square$ Healthy Debate, 21 July 2016, viewed 25 September 2017, http://healthydebate.ca/2016/07/topic/harm-reduction-hospitals-injection-opioids.

Goodman, J.D. and Hartocollis, A. (2014) Anti-overdose drug becoming an everyday part of police work $\square$ New York Times, 12 June 2014, viewed 14 October 2017,

www.nytimes.com/2014/06/13/nyregion/anti-overdose-drug-becoming-an-everyday-part-ofpolice-work.html? $r=1$.

Grabosky, P. (1997) [nside the pyramid: Towards a conceptual framework for the analysis of regulatory systems $\square$ nternational Journal of the Sociology of Law, 25(3): 195201.

Grabosky, P. (2010) On the interface of criminal justice and regulation $\square$ n H. Quirk, T. Seddon and G. Smith (eds), Regulation and Criminal Justice. Cambridge: Cambridge University Press. Grabosky, P. (2013) Beyond responsive regulation: The expanding role of non-state actors in

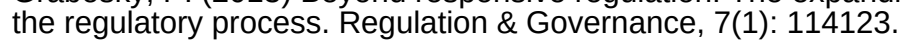

Grabosky, P. and Braithwaite, J. (1986) Of manners gentle: Enforcement strategies of Australian business regulatory agencies. Melbourne: Oxford University Press.

Graveland, B. (2016) Calgary police chief wants action on opioid crisis $\square$ The Toronto Star, 27 December 2016, viewed 14 October 2017, www.thestar.com/news/canada/2016/12/27/calgary- 
police-chief-wants-action-on-opioid-crisis.html.

Hewitt, L. (2017) Bsychiatric emergency services will relieve policy from mental health 911 calls $\square$ Portland Tribune, viewed 9 January 2017, viewed 25 September 2017,

www.pamplinmedia.com/pt/9-news/339199-219318-psychiatric-emergency-services-will-relieveportland-police-from-mental-health-911-calls.

Hibdon, J. and Groff, E.R. (2014) W/hat you find depends on where you look: Using emergency medical services call data to target illicit drug use hot spots $\square$ Journal of Contemporary Criminal Justice, 30(2): $169 \mathbb{1 1 8 5 .}$

International Network of Drug Consumption Rooms (2017) Germany lan overview. Viewed 14 October 2017, www.drugconsumptionroom-

international.org/index.php/locations/germany/location-germany.

Ireland, N. (2016) The year of the fentanyl crisis: How we got here $\square$ CBC News, 24 December 2016, viewed 14 October 2017, www.cbc.ca/news/health/fentanyl-carfentanil-opioid-crisisspreading-across-canada-1.3909986.

Ivsins, A. , Chow, C. , Macdonald, S. , Stockwell, T. , Vallance, K. , Marsh, D.C. , Michelow, W. and Duff, C. (2012) An examination of injection drug use trends in Victoria and Vancouver, BC after the closure of Victoriaslonly fixed-site needle and syringe programme nnternational Journal of Drug Policy, 23(4): 338340.

Jones, Y. (2016) Memphis police crisis intervention team works to defuse mental health calls $\square$ The Commercial Appeal, 5 March 2016, viewed 25 September 2017,

http://archive.commercialappeal.com/news/memphis-police-crisis-intervention-team-works-todefuse-mental-health-calls-2c9bba98-fe28-1e3b-e053-371108951.html.

66 Kirkup, K. (2016) Medical experts urge Canada to declare public emergency over opioid crisis $\square$ CBC News, 18 November 2016, viewed 14 October 2017,

www.cbc.ca/news/politics/opioid-crisis-meeting-1.3856740.

Lahey, T. (2017) Det opioid users inject in hospitals $\square$ New York Times, 6 January 2017, viewed 25 September 2017, www.nytimes.com/2017/01/06/opinion/let-opioid-users-inject-in-

hospitals.html?emc=edit_th_20170106\&nl=todaysheadlines\&nlid=70363278\&_r=0.

Lavalley, A. (2016) Doroner: Police saved 33 lives with Narcan in 2016ロChicaḡo Tribune, 15 December 2016, viewed 14 October 2017, https://flipboard.com/@flipboard/flip.it\%2FLtn8shcoroner-police-saved-33-lives-with-narc/f-738f7095f2\%2Fchicagotribune.com.

LEAD (2017) About LEAD. Viewed 14 October 2017, http://leadkingcounty.org/about/.

Los Angeles Police Department (2011) The Los Angeles Police DepartmentSmental evaluation unit\$mental illness project is selected as a bright ideas recipient. Viewed 25 September 2017 , www.lapdonline.org/march_2011/news_view/47571.

Mazerolle, L. and Ransley, J. (2006) Third party policing. Cambridge: Cambridge University Press.

McKenna, B. , Furness, T. , Brown, S. , Tacey, M. , Hiam, A. and Wise, M. (2015) Bolice and clinician diversion of people in mental health crisis from the emergency department: $A$ trend analysis and cross comparison study[BMC Emergency Medicine, 15(1): 14.

NHS England (2017) About mental health. Viewed 14 October 2017, www.england.nhs.uk/mentalhealth/about/.

ODeill, S. (2015) Bolice and the mentally ill: LAPD united praised as model for nation $\square 89.3$ KPCC, 9 March 2015, viewed 25 September 2017,

www.scpr.org/news/2015/03/09/50245/police-and-the-mentally-ill-lapd-unit-praised-as-m/.

Office of the Assistant Attorney General (2014) Department of JusticeScivil investigation of the Albuquerque Police Department. Viewed 15 October 2017,

www.justice.gov/sites/default/files/crt/legacy/2014/04/10/apd_findings_4-10-14.pdf.

Oliva, J.R. and Comptson, M.T. (2008) ब statewide crisis intervention team (CIT) initiative:

Evolution of the Georgia CIT program Dournal of the American Academy of Psychiatry and the Law Online, 36(1): 3846.

Open Society Foundations (2014) To protect and service: How police, sex workers, and people who use drugs are joining forces to improve health and human rights. Viewed 25 September

2017, www.opensocietyfoundations.org/sites/default/files/protect-serve-20140716.pdf.

Osher, F. , DAmora, D.A. , Plotkin, M. , Jarrett, N. and Eggleston, A. (2012) Adults with

behavioral health needs under correctional supervision. Viewed 25 September 2017,

www.bja.gov/Publications/CSG_Behavioral_Framework.pdf.

Pearce, M. (2014) A swift lifesaver in heroin overdoses viewed 10 October 2017, http://articles.latimes.com/2014/feb/06/nation/la-na-heroin-antidote20140206.

Police Executive Research Forum (2016) Guiding principles on the use of force. Viewed 15 October 2017, www.policeforum.org/assets/guidingprinciples1.pdf.

President巨Task Force on 21st Century Policing (2015) Final report of the PresidentEtask force on 21st century policing. Viewed 25 September 2017, 
www.cops.usdoj.gov/pdf/taskforce/taskforce finalreport.pdf.

67 Punch, M. (1979) The secret social service $\square n$ S. Holdaway (ed.), The British Police. London: Arnold.

Rahr, S. and Rice, S.K. (2015) From warriors to guardians: Recommitting American police culture to democratic ideals. Viewed 15 October 2017,

www.hks.harvard.edu/content/download/76023/1708385/version/1/file/WarriorstoGuardians.pdf. Ransley, J. (2016) Bolicing through third parties: Increasing coercion or improving legitimacy? $\square$ Sociology of Crime, Law, and Deviance, 21: 4158.

Rudd, R.A. , Aleshire, N. , Zibbell, J.E. and Gladden, M. (2016) mcreases in drug and opioid overdose deaths 凹nited States, 200020140Morbidity and Mortality Weekly Report, 64(50): 1378 प1382.

Rudd, R.A. , Seth, P. , David, F. and School, L. (2016) நncreases in drug and opioid-involved overdose deaths $\amalg$ nited States, 20102015 Morbidity and Mortality Weekly Report, 65(5051): $1445 \square 452$.

Ryan, F. (2015) Combatting opiate addiction: A strategy by the Arlington police department. Viewed 25 September 2017, http://paariusa.org/wpcontent/uploads/sites/46/2015/08/20150723101427154.pdf.

Santos, F. and Goode, E. (2014) Bolice confront rising number of mentally ill suspects $\square$ New York Times, 1 April 2014, viewed 15 October 2017, www.nytimes.com/2014/04/02/us/policeshootings-of-mentally-ill-suspects-are-on-the-upswing.html.

Schiff, D.M. , Drainoni, M.L. , Bair-Merritt, M. , Weinstein, Z. and Rosenbloom, D. (2016) A police-led addiction treatment referral program in Massachusetts: Letter $\square$ The New England Journal of Medicine, 375(25): 2502.

Schwarzfeld, M. , Reuland, M. and Plotkin, M. (2008) Improving responses to people with mental illnesses: The essential elements of a specialized law enforcement-based program. Viewed 15 October 2017, www.bja.gov/Publications/LE_Essential_Elements.pdf.

Shearing, C. (2003) A constitutive conception of regulation Dn P. Grabosky and J. Braithwaite (eds), Business Regulation and Australias Future. Canberra: Australian Institute of Criminology, pp. 6780 .

Simon, J. (2007) Governing through crime: How the war on crime transformed American democracy and created a culture of fear. Oxford: Oxford University Press.

Steadman, H.J. , Morrisey, J.P. , Deane, M.W. and Borum, R. (1999) Police response to emotionally disturbed persons: Analyzing new models of police interactions with the mental health system. Viewed 25 September 2017, www.ncjrs.gov/pdffiles1/nij/grants/179984.pdf. Steering Committee for the Review of Government Service Provision (2016) Overcoming Indigenous disadvantage: Key indicators 2016. Viewed 25 September 2017,

www.pc.gov.au/research/ongoing/overcoming-indigenous-disadvantage/2016/report-

documents/oid-2016-overcoming-indigenous-disadvantage-key-indicators-2016-report.pdf.

Stueck, W. , Hager, M. and Hume, M. (2016) B.C. health authorities flood streets with opioid antidote [The Globe and Mail, 21 December 2016, viewed 25 September 2017,

www.theglobeandmail.com/news/british-columbia/bc-health-authorities-flood-streets-with-opioidantidote/article33409106/.

Subramanian, R. , Delaney, R. , Roberts, S. , Fishman, N. and McGarry, P. (2015)

Incarcerations front door: The misuse of jails in America. Viewed 15 October 2017, http://archive.vera.org/sites/default/files/resources/downloads/incarcerations-front-doorreport.pdf.

68 Teplin, L.A. (1986) Keeping the peace: The parameters of police discretion in relation to the mentally disordered. USA: US Department of Justice.

Teplin, L.A. and Pruett, N.S. (1992) Bolice as streetcorner psychiatrist: Managing the mentally illunternational Journal of Law and Psychiatry, 15(2), 139156.

Toussaint, K. (2017) Gloucester police program helps nearly 400 addicts in first year $\square$ Metro, 22 December 2016, viewed 25 September 2017, www.metro.us/boston/gloucester-angel-programhelps-nearly-400-addicts-in-first-year/zsJplv-hB22SGNXkUZfg/.

Town of Arlington (2015) Arlington Police Department implements new addiction protocols. Viewed 10 October 2017,

www.arlingtonma.gov/Home/Components/News/News/3078/494?arch=1.

Travis, A. (2016) One prison suicide every three days in England and Wales, say reformers $\square$ Guardian, 28 November 2016, viewed 10 October 2017, www.the-

guardian.com/society/2016/nov/28/one-prison-suicide-every-three-days-england-and-walessay-reformers.

UK Department of Health (2013) Extending the street triage scheme: New patrols with nurses and the police. Viewed 25 September 2017, www.gov.uk/government/news/extending-thestreet-triage-scheme-new-patrols-with-nurses-and-the-police. 
University of Memphis CIT Center (2017) Announcements. Viewed 15 October 2017, www.cit.memphis.edu/.

Van Steden, R. , Wood, J. , Shearing, C. and Boutelier, H. (2014) The many faces of nodal policing: Team play and improvisation in Dutch community safety $\square$ Security Journal, 29(3): 327B339.

Washington Post (2017) 991 people shot dead by police in 2015. Viewed 15 October 2017, www.washingtonpost.com/graphics/national/police-shootings/.

Watson, A.C. , Ottati, V.C. , Draine, J. and Morabito, M. (2011) CIT in context: The impact of mental health resources availability and district saturation on call dispositions $\square$ nternational Journal of Law and Psychiatry, 34(4): 287294.

Watson, A.C. , Ottati, V.C. , Morabito, M. , Draine, J. , Kerr, A.N. and Angell, B. (2010)

Outcomes of police contacts with persons with mental illness: The impact of CITDAdministration and Policy in Mental Health and Mental Health Services Research, 37(4): 3023117.

Werb, D. , Kerr, T. , Buxton, J. , Shoveller, J. , Richardson, C. , Montaner, J. and Wood, E. (2013) Batterns of injection drug use cessation during an expansion of syringe exchange services in a Canadian setting Drug and Alcohol Dependence, 132(3): 535540.

White, M.D. , Goldkamp, J.S. and Campbell, S.P. (2006) Co-occurring mental illness and substance abuse in the criminal justice system: Some implications for local jurisdictions $\square$ The Prison Journal, 86(3): 301B26.

Woo, A. (2016) Dancouver approves tax to fund response to opioid overdose crisis $\square$ The Globe and Mail, 13 December 2016, viewed 25 September 2017,

www.theglobeandmail.com/news/british-columbia/vancouver-approves-tax-to-help-firstresponders-battling-opioid-crisis/article33314671/.

Wood, J. and Shearing, C. (2007) Imagining security. Cullompton: Willan.

Wood, J. and Watson, A. (2017) Enproving police interventions during mental health-related encounters: Past, present and future $P$ Policing and Society, 27(3): 289299.

Wood, J. , Swanson, J.W. , Burris, S. and Gilbert, A. (2011) Police interventions with persons affected by mental illnesses: A critical review of global thinking and practice. Rutgers University, New Jersey: 69 Center for Behavioral Health Services and Criminal Justice Research.

Wood, J. , Watson, A. and Fulambarker, A. (2017) The gray zone 0 f police work during mental health encounters: Findings from an observational study in Chicago Police Quarterly, 20(1): $81 \mathbb{1 1 0 5}$.

Wooditch, A. , Lawton, B. and Taxman, F.S. (2013) The geography of drug abuse epidemiology among probationers in Baltimore $\square$ Journal of Drug Issues, 43(2): 231249.

Yeung, P. (2016) Rise in prisoners moved to mental health hospitals. Viewed 25 September 2017, www.theguardian.com/society/2016/sep/14/mental-health-problems-male-prisonershospital-treatment-ministry-of-justice-figures?CMP=Share_AndroidApp_OneNote.

\section{Co-producing prosecution}

Alford, J. (2009) Engaging public sector clients: From service-delivery to co-production.

Basingstoke, UK: Palgrave Macmillan.

Ayling, J. (2013) Barnessing third parties for transnational environmental crime prevention $\square$ Transnational Environmental Law, 2(2): 339362.

81 Ayres, I. and Braithwaite, J. (1991) Tripartism: Regulatory capture and empowerment and Society Inquiry, 16(3): 435496.

Ayres, I. and Braithwaite, J. (1992) Responsive regulation: Transcending the deregulation debate. Oxford, UK: Oxford University Press.

Bartley, T. (2007) [nstitutional emergence in an era of globalization: The rise of transnational private regulation of labor and environmental conditions DAmerican Journal of Sociology, 113(2): 297351.

Bayley, D. and Shearing, C. (2001) The new structure of policing: Description, conceptualisation and research agenda. Washington, DC: National Institute of Justice.

BBC News (2017) Stephen Lawrence murder: A timeline of how the story unfolded. Viewed 21 February 2017, www.bbc.com/news/uk-26465916.

Black, J. (2008) Constructing and contesting legitimacy and accountability in polycentric

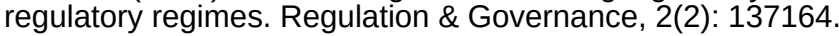

Brandsen, T. and Pestoff, V. (2006) Do-production, the third sector and the delivery of public services $\square$ Public Management Review, 8(4): 493501.

Brewer, R. (2014) Policing the waterfront: Networks, partnerships and the governance of port security. Oxford, UK: Oxford University Press. 
Buerger, M. and Mazerolle, L. (1998) Third party policing: A theoretical analysis of an emerging trendDJustice Quarterly, 15(2): 301328.

Cody, S. , Stover, E. , Balthazard, M. and Koenig, A. (2015) The VictimsCourt? A study of 622 victim participants at the International Criminal Court. Berkeley, CA: Human Rights Centre, University of California.

Cornwall, A. (2008) Unpacking plarticipation $\square$ Models, meanings and practices $\square$ Community Development Journal, 43(3): 269283.

Cowdery, N. (1995) Bot seat or SiberiaПJournal of the NSW Bar Association, 5.

DCruze, S. (1999) Sex, violence and local courts British Journal of Criminology, 39(1): 3955.

Dupont, B. , Grabosky, P. and Shearing, C. (2003) Dhe governance of security in weak and failing states $\square$ Criminal Justice, 3(4): 331349.

Dzur, A. (2012) Punishment, participatory democracy, and the jury. Oxford, UK: Oxford University Press.

Extraordinary Chambers in the Courts of Cambodia (2015) Victims support section. Viewed 22 February 2017, www.eccc.gov.kh/en/victims-support/victims-support-section.

Findlay, M. (2009) Activating a victim constituency in international criminal justice International Journal of Transitional Justice, 3(2):183206.

Ford, M. and Vukovic, D. (2017) Dynette Daley: Adrian Attwater, Paul Maris found guilty over 2011 camping trip deathDABC News, 6 September 2017, viewed 20 October 2017, www.abc.net.au/news/2017-09-06/lynette-daley-trial-delivers-guilty-verdicts/8878848.

Friedman, D. (1995) Making sense of English law enforcement in the eighteenth century $\square$ University of Chicago Law School Roundtable, 2: 475505.

Galanter, M. (1974) Why the haves Come out ahead: Speculations on the limits of legal change Law \& Society Review, 9(1), 95ஐ60.

Glasius, M. (2002) Expertise in the cause of justice: Global civil society influence on the statute for an International Criminal Court $\square$ n M. Glasius, M. Kaldor and H. Anheier (eds), Global civil society yearbook 2002. Oxford, UK: Oxford University Press.

82 Gobert, J. (2005) The politics of corporate manslaughter-the British experience $\square$ Flinders Journal of Law Reform, 8(1): 1.

Grabosky, P. (1992a) Daw enforcement and the citizen: Non-governmental participants in crime prevention and control $\square$ Policing and Society, 2(4): 249271.

Grabosky, P. (1992b) Prosecutors, informants, and the integrity of the justice system $\square$ Current Issues in Criminal Justice, 4(1): 4763.

Grabosky, P. (1994) Green markets: Environmental regulation by the private sector $\square$ aw and Policy, 16(4): 419448.

Grabosky, P. (1995) Dsing non-governmental resources to foster regulatory compliance $\square$ Governance: An International Journal of Policy and Administration, 8(4): 527550.

Grabosky, P. (2001) Orime control in the 21st century $\square$ The Australian and New Zealand Journal of Criminology, 34(3): 221234.

Grabosky, P. (2007) Security in the 21st century $\square$ Security Journal, 20(1): 9패.

Grabosky, P. (2010) On the interface of criminal justice and regulation $\square$ n H. Quirk, T. Seddon and G. Smith (eds) Regulation and Criminal Justice. Cambridge, UK: Cambridge University Press.

Grabosky, P. (2013) Beyond responsive regulation: The expanding role of non-state actors in

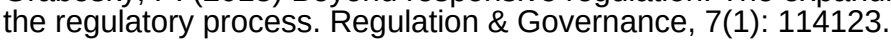

Grabosky, P. and Braithwaite, J. (1986) Of manners gentle: Enforcement strategies of Australian business regulatory agencies. Melbourne: Oxford University Press.

Hay, D. and Snyder, F. (1989) Policing and prosecution in Britain, 1750ח850. UK: Clarendon Press.

Healy, J. (2016) Improving health care safety and quality: Reluctant regulators. London, UK: Routledge.

Holder, R. (2016) Dntangling the meanings of justice: A longitudinal mixed method study $\square$ Journal of Mixed Methods Research, 1 III7.

Holder, R. and Whiting, S. (2016) Boyal commission into institutional responses to child sexual abuse: Consultation paper on criminal justice[Viewed 25 February 2017,

http://childabuseroyalcommission.gov.au/getattachment/5f67ada5-43e2-4a3a-a030-

51ed31b3bdd5/Dr-Robyn-Holder-and-Ms-Suzanne-Whiting.

Innes, M. and Roberts, C. (2008) Beassurance policing, community intelligence and the coproduction of neighbourhood order $\square \mathrm{n} \mathrm{T}$. Williamson (ed), The handbook of knowledge-based policing: Current conceptions and future directions. Chichester, UK: Wiley.

International Criminal Court (2017) Victims before the international criminal court: A guide for the participation of victims in the proceedings of the court. Viewed 24 February 2017, www.icccpi.int/NR/rdonlyres/8FF91A2C-5274-4DCB-9CCE- 
37273C5E9AB4/282477/160910VPRSBookletEnglish.pdf.

Johnston, L. (1999) Private policing: Uniformity and diversity $\square n$ R.I. Mawby (ed), Policing across the world: Issues for the twenty-first Century. London, UK: UCL Press.

Karstedt, S. (2010) Erom absence to presence, from silence to voice: Victims in international and transitional justice since the Nuremberg Trials $\square$ nternational Review of Victimology, 17(1): 930 .

King, P. (1984) Decision-makers and decision-making in the English criminal law, 1750ח800 The Historical Journal, 27(1): 2558.

Kirchengast, T. (2017) Victimology and victim rights: International comparative perspectives. Oxford, UK: Routledge.

83 Langbein, J. (2003) The origins of the adversary criminal trial. Oxford, UK: Oxford University Press.

Lemmings, D. (2005) Criminal trial procedure in eighteenth-century England: The impact of lawyers $\square$ The Journal of Legal History, 26(1): 738D.

Little, C. and Sheffield, C. (1983) Erontiers and criminal justice: English private prosecution societies and American vigilantism in the Eighteenth and Nineteenth Centuries $\square$ American Sociological Review, 48(6): 796808.

Luna, E. and Wade, M. (2012) The prosecutor in transnational perspective. Oxford, UK: Oxford University Press.

Mansbridge, J. , Bohman, J. , Chambers, S. , Estlund, D. , Fllesdal, A. , Fung, A. , Lafont, C. , Manin, B. and Mart, $\square$. (2010) The place of self-interest and the role of power in deliberative democracy The Journal of Political Philosophy, 18(1): 64प00.

Matravers, M. (2010) The victim, the state, and civil society $\mathrm{nn}$ A. Bottoms and J. Roberts (eds), Hearing the victim: Adversarial justice, crime victims and the State. Cullompton, UK: Willan Publishing.

Mazerolle, L. and Ransley, J. (2005) Third party policing. Cambridge, UK: Cambridge University Press.

Mullenbach, M. (2005) Deciding to keep peace: An analysis of international influences on the establishment of third party peacekeeping missions $\square$ nternational Studies Quarterly, 49(3):

529556.

National Crime Victim Law Institute (2017) NCVLI home. Viewed 22 February 2017, http://law.Iclark.edu/centers/national_crime_victim_law_institute/.

OConnell, M. (2016) Boyal commission into institutional responses to child sexual abuse:

Consultation paper Criminal justice DViewed 25 February 2017,

http://childabuseroyalcommission.gov.au/getattachment/a64ef798-0fc3-451b-bbb1-

a7eb2b9f09a5/SA-Commissioner-for-Victims\%E2\%80\%99-Rights-2.

Ogus, A. (2004) Regulation: Legal, form and economic theory. Oxon, UK: Hart Publishing.

Ostrom, E. (1999) Crossing the great divide: Co-production, synergy, and development $\square$ World Development, 24(6): 1073ா087.

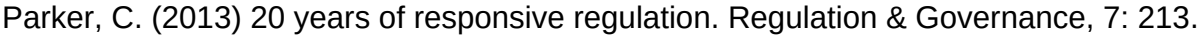

Pestoff, V. (2006) Ditizens and co-production of welfare services: Childcare in eight European countries Public Management Review, 8(4): 5035119.

Pohl, C. , Rist, S. , Zimmermann, A. , Fry, P. , Gurung, G. , Schneider, F. , Speranza, C. , Kiteme, B. , Boillat, S. , Serrano, E. and Hadorn, G. (2010) Besearchersచoles in knowledge coproduction: Experience from sustainability research in Kenya, Switzerland, Bolivia and Nepal $\square$ Science and Public Policy, 37(4): 267281.

Putt, J. , Holder, R. and OCeary, C. (2017) WomenElspecialist domestic and family violence services: Their responses and practices with and for Aboriginal women: Final Report. Sydney: ANROWS.

Rock, P. (2004) Dictims, prosecutors and the state in nineteenth century England and Wales $\square$ Criminal Justice, 4(4): 331354.

Sarat, A. and Clarke, C. (2008) Beyond discretion: Prosecution and the logic of sovereignty, and the limits of law口aw and Social Inquiry, 33(2): 387416.

Sarre, R. (2007) White-collar crime and prosecution for Ddustrial manslaughter [as a means to reduce workplace deaths $\square \mathrm{n} \mathrm{H}$. Pontell and G. Geis (eds), International Handbook of whitecollar and corporate crime. US: Springer, pp. 648662.

84 Scheingold, S. (2004) The politics of rights: Lawyers, public policy, and political change. Ann Arbor, Ml: University of Michigan Press.

Sklansky, D. (2017) The problems with prosecutors $\square$ Annual Review of Criminology, 14(16): 2.1219.

Sperfeldt, C. (2017) The trial against Hissne HabrDNetworked justice and reparations at the extraordinary African chambers $\square$ The International Journal of Human Rights, 21(9): 1243ா260.

Stenning, P. (2008) The modern prosecution process in New Zealand. Wellington, NZ: Victoria University Press. 
Stevenson, K. (2004) Eulfilling their mission: The intervention of voluntary societies in cases of sexual assault in the Victorian criminal process $\square$ Crime, History \& Societies, 8(1): 93

Strang, H. (2002) Repair or revenge: Victims and restorative justice. Oxford, UK: Clarendon Press.

Van Dijk, J. , van Kesteren, J. and Smit, P. (2007) Criminal victimisation in international perspective. Den Haag: International Specialised Book Service.

Victims Rights Working Group (2007) Who we are. Viewed 22 February 2017,

www.vrwg.org/about-vrwg/who-we-are.

Victorian Law Reform Commission (VLRC) (2016) The role of victims of crime in the criminal trial process. Melbourne: VLRC.

Womens Initiatives for Gender Justice (2017) Home. Viewed 22 February 2017,

http://4genderjustice.org/.

Woods, G. (2002) A history of criminal law in New South Wales: The colonial period 1788प1900. Sydney: The Federation Press.

Zemans, F. (1983) Degal mobilization: The neglected role of the law in the political system[The American Political Science Review, 77(3): 690703.

\section{Non-state actors as brokers of crime control}

AFP (2009) PJC-ACC Inquiry into the Adequacy of Aviation and Maritime Security Measures to Combat Serious and Organised Crime: AFP Submission. Canberra: Australian Federal Police.

Albrecht, T.L. and Ropp, V.A. (1982) The study of network structuring in organizations through the use of method triangulation $\square$ The Western Journal of Speech Communication, 46(2): 162 [178.

Ayling, J. , Grabosky, P. and Shearing, C. (2009) Lengthening the arm of the law: Enhancing police resources in the twenty-first century. Cambridge: Cambridge University Press.

Bayley, D.H. and Shearing, C. (2001) The new structure of policing: Description, conceptualization, and research agenda. Washington, DC: National Institute of Justice, US Department of Justice.

Block, A. (1982) On the waterfront revisited: The criminology of waterfront organized crime $\square$ Crime, Law and Social Change, 6(4): 373396.

Boissevain, J. (1974) Friends of friends: Networks, manipulators, and coalitions. Oxford: Basil Blackwell.

Borgatti, S.P. , Everett, M.G. and Freeman, L.C. (2002) UCINET for Windows: Software for social network analysis. Harvard, MA: Analytic Technologies.

Boutellier, H. and van Steden, R. (2011) Governing nodal governance: The छnchoring $6 f$ local security networks $\square$ n A. Crawford (ed.), International and comparative criminal justice and urban governance: Convergence and divergence in global, national and local settings. Cambridge, UK: Cambridge University Press, pp. 461482.

Brewer, R. (2014) Policing the waterfront: Networks, partnerships, and the governance of port security. Oxford: Oxford University Press.

106 Brewer, R. (2017) Dontrolling crime through networks $\square n$ P. Drahos (ed.), Regulation, institutions and networks. Canberra: ANU Press.

Brewer, R. and Grabosky, P. (2014) The unraveling of public security in the United States: The dark side of police-community co-production $\square$ American Journal of Criminal Justice, 39(1): 139 II54.

Broll, R. (2014) Collaborative responses to cyberbullying: Preventing and responding to cyberbullying through nodes and clusters $\square$ Policing \& Society, 26(7): 735752.

Burt, R.S. (1987) A note on missing network data in the general social survey $\square$ Social Networks, 9(1): 63Z3.

Burt, R.S. (1992) Structural holes: The social structure of competition. Cambridge, MA: Harvard University Press.

Burt, R.S. (2005) Brokerage and closure: An introduction to social capital. Oxford: Oxford University Press.

Cherney, A. (2008) Barnessing the crime control capacities of third parties $\square$ Policing: An International Journal of Police Strategies \& Management, 31(4): 631647.

Cherney, A. , OBeilly, J. , and Grabosky, P. (2006a) The multilateralization of policing: The case of illicit synthetic drug control $\square$ Police Practice and Research, 7(3): 177 प194.

Cherney, A. , OBeilly, J. , and Grabosky, P. (2006b) Detworks and meta-regulation: Strategies aimed at governing illicit synthetic drugs $\square$ Policing \& Society, 16(4): 370385. 
Clauset, A. , Newman, M.E.J. , and Moore, C. (2004) Einding community structure in very large networks $\square$ Physical Review E, 70(6): 16

Corbin, J. and Strauss, A. (1990) Grounded theory research DQualitative Sociology, 13(1): 3211.

Crawford, A. (2006a) Detworked governance and the post-regulatory state? Steering, rowing and anchoring the provision of policing and security पTheoretical Criminology, 10(4): 449479.

Crawford, A. (2006b) Bolicing and security as Dlub goods TThe new enclosures? [n J. Wood and B. Dupont (eds), Democracy, society and the governance of security. Cambridge: Cambridge University Press, pp. 111[38.

Crawford, A. , Lister, S. , Blackburn, S. , and Burnett, J. (2005) Plural policing: The mixed economy of visible patrols in England and Wales. Bristol: The Policy Press.

De Lint, W. (2003) Keeping open windows: Police as access brokers $\square$ British Journal of Criminology, 43(2): 379397.

Dupont, B. (2004) Security in the age of networks $\square$ Policing \& Society, 14(1): 7691.

Dupont, B. (2006a) Bower struggles in the field of security $\mathrm{n}$ J. Wood and B. Dupont (eds),

Democracy, society and the governance of security. Cambridge: Cambridge University Press, pp. 86П110.

Dupont, B. (2006b) Delivering security through networks: Surveying the relational landscape of security managers in an urban setting $\square$ Crime, Law and Social Change, 45(3): $165 \square 84$.

Ericson, R.V. and Haggerty, K.D. (1997) Policing the risk society. Toronto: University of Toronto Press.

Fleming, J. (2006) Working through networks: The challenge of partnership policing $\square \mathrm{n}$ : J.

Flemming and J. Wood (eds), Fighting crime together: The challenges of policing and security networks. Sydney: UNSW Press, pp. 87m15.

Giddens, A. (1990) The consequences of modernity. Stanford: Stanford University Press.

107 GHD (2013) Port of Melbourne traffic surveys summary report. Melbourne.

Gould, R.V. and Fernandez, R.M. (1989) Structures of mediation: A formal approach to

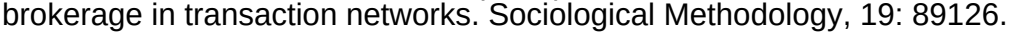

Grabosky, P. (1992) Daw enforcement and the citizen: Non-government participants in crime prevention and control $\square$ Policing \& Society, 2(4): 2492771.

Grabosky, P. (1996) The future of crime control[DAIC trends and issues. Canberra: Australian Institute of Criminology.

Greene, J.R. (2000) Community policing in America: Changing the nature, structure, and function of the police. Washington, DC: National Institute of Justice, US Department of Justice.

Johnston, L. , Button, M. , and Williamson, T. (2008) Bolice, governance and the private finance initiative + Policing \& Society, 18(3): 225244.

Kossinets, G. (2006) Effects of missing data in social networks $\square$ Social Networks, 28(3): 247268. Loader, I. (2000) Blural policing and democratic governance $\square$ Social and Legal Studies, 9(3): $323 B 45$.

Loader, I. and Walker, N. (2006) Decessary virtues: The legitimate place of the state in the production security $\square$ n J. Wood and B. Dupont (eds), Democracy, society and the governance of security. Cambridge: Cambridge University Press, pp. $165 \mathbb{1 9 5}$.

Macaulay, S. (1986) Brivate government $\square$ n L. Lipson and S. Wheeler (eds), Law and the Social Sciences. New York: Russell Sage Foundation, pp. 445511.

Marks, M. , Wood, J. , Azzopardi, J. and Xaba, T. (2011) Beconfiguring state and non-state actors in the provision of safety in (South) Africa: Implications for bottom-up policing arrangements and for donor funding Dournal of Legal Pluralism and Unofficial Law, 49(63): 4972 .

Marks, P. , van Sluis, A. , Vervooren, A. and Zeer, M. (2013) Enproving policing in the port of Rotterdam, the Netherlands $\square$ n S.C. Taylor, D.J. Torpy, and D.K. Das (eds), Policing global movement tourism, migration, human trafficking, and terrorism. Florida, USA: CRC Press, pp. 2139.

Marsden, P.V. (1982) Brokerage behavior in restricted exchange networks $\square$ n P. Marsden and N. Lin (eds), Social structure and network analysis. Beverly Hills: Sage, pp. 2012118.

Marshall, M.N. (1996) Slampling for qualitative research $\square$ Family Practice, 13(6): 522525.

Moore, M.H. and Alpert, G.P. (1993) Measuring police performance in the new paradigm of policing $\square$ n Performance measures for the criminal justice system, Washington, DC: Bureau of Justice Statistics Princeton University, pp. 1 [1]6.

Morselli, C. (2009) Inside criminal networks. New York: Springer.

Morton, J. and Robinson, R. (2010) Shotgun and standover: The story of the painters and dockers. Sydney: Macmillan.

Parker, C. and Braithwaite, J. (2003) BegulationDn P. Cane and M. Tushnet (eds), The Oxford handbook of legal studies. Oxford: Oxford University Press, pp. 119ד45. 


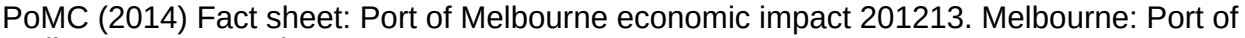
Melbourne Corporation.

Reiner, R. (2010) The politics of the police. New York: Oxford University Press.

Shearing, C. (2006) Beflections on the refusal to acknowledge private governments $\square$ n J. Wood and B. Dupont (eds), Democracy, society and the governance of security. Cambridge:

Cambridge University Press, pp. $11 B 2$.

108 Shearing, C. (2007) Bolicing our future Dn A. Henry and D. Smith (eds), Transformations of Policing. Aldershot: Ashgate.

Shearing, C. and Wood, J. (2003) Dodal governance, democracy, and the new denizens $\square$ Journal of Law and Society, 30(3): 400419.

Shearing, C. and Johnston, L. (2010) Dodal wars and network fallacies: A genealogical analysis of global insecurities पTheoretical Criminology, 14(4): 495514.

Smith, M. , Milac-Frayling, N. , Schneiderman, B. , Mendes Rodrigues, E. , Leskovec, J. and Dunne, C. (2010) Network overview, discovery and exploration for Excel. Viewed 24 October 2014, http://nodexl.codeplex.com/.

Steden, R.V. , Wood, J. , Shearing, C. , and Boutellier, H. (2013) The many faces of nodal policing: Team play and improvisation in Dutch community safety $\square$ Security Journal, 29(3): 327B39.

Stork, D. and Richards, W.D. (1992) Donrespondents in communication network studies: Problems and possibilities [Group \& Organization Management, 17(2): 193209.

Taube, V. (2004) Measuring the social capital of brokerage roles $\square$ Connections, 26(1): 2952. Wasserman, S. and Faust, K. (1994) Social network analysis: Methods and applications. Cambridge: Cambridge University Press.

Wood, J. and Dupont, B. (2006) Democracy, society and the governance of security. Cambridge: Cambridge University Press.

Zegart, A.B. , Hipp, M.C. and Jacobson, S.K. (2005) Port security: Improving emergency response capabilities at the ports of Los Angeles and Long Beach. Los Angeles: UCLA School of Public Affairs.

\section{Using regulatory pluralism to achieve effective control of Somali piracy}

Advisory Council on International Affairs (2010) Combating piracy at sea: A reassessment of public and private responsibilities. Advisory Report, 72. Viewed 20 May 2017, https://aivadvies.nl/download/045f9ea5-c9f0-4bb6-a3c0-bc190e56dbaa.pdf.

BBC News (2010) Anti-pirate attack guidelines being ignored, UN says. Viewed 20 May 2017, http://news.bbc.co.uk/2/hi/8487837.stm.

Bell, C. , Lawellin, B. , Amling, A. , Benson, J. , Egorova, S. , Filitz, J. , Pigeon, M. and Roberts, P. (2017) Stable seas: Somali waters. Viewed 15 September 2017,

http://oefresearch.org/sites/default/files/documents/publications/Stable_Seas_Somali_Waters_F INAL.pdf.

128 Biegon, R. (2009) Somali pirates and the international response. Viewed 20 May 2017, www.fpif.org/articles/somali-piracy-and-the-international-response.

Bowden, A. and Basnet, S. (2012) The economic cost of Somali piracy 2011: Working paper. Viewed 15 September 2017,

http://oceansbeyondpiracy.org/sites/default/files/economic_cost_of_piracy_2011.pdf.

Bowden, A. , Hurlburt, K. , Marts, C. , Lee, A. and Aloyo, E. (2010) The economic costs of maritime piracy. Viewed 17 September 2017,

www.steamshipmutual.com/Downloads/Piracy/EconomicCostPiracyOEFReport.pdf.

Brewer, R. and Grabosky, P. (2014) The unraveling of public security in the United States: The dark side of police-community co-productionDAmerican Journal of Criminal Justice, 39(1): 139 II54.

Braithwaite, J. and Drahos, P. (2000) Global business regulation. Cambridge, UK: Cambridge University Press.

Bronshteyn, I. (2010) Piracy off the coast of Somalia. Viewed 17 September 2017, www.slideshare.net/HAXAJIKA/irina-bronshteyn-piracy-off-the-coast-of-

somalia?from=share_email.

Chayes, A. and Chayes, A. (1995) The new sovereignty: Compliance with international regulatory regimes. Cambridge, MA: Harvard University Press.

Combined Maritime Forces (n.d.) CTF 151: Counter-piracy. Viewed 15 September 2017, https://combinedmaritimeforces.com/ctf-151-counter-piracy. 
Contact Group on Piracy off the Coast of Somalia (2013) Fourteenth plenary session of the Contact Group on Piracy off the Coast of Somalia. Viewed 15 September,

www.thecgpcs.org/plenary.do?action=plenarySub\&seq=23.

Dupont, B. (2006) Delivering security through networks: Surveying the relational landscape of security managers in an urban setting $\square$ Crime, Law and Social Change, 45(3): $165 \mathbb{1} 84$.

Dupont, B. , Grabosky, P. , and Shearing, C. (2003) The governance of security in weak and failing states $\square$ Criminal Justice, 3(4): 331349.

EU NAVFOR (2011) BMP4: Best management practices for protection against Somalia based piracy 2011. Edinburgh: Witherby.

Gilpin, R. (2007) Enhancing maritime security in the Gulf of Guinea. Viewed 17 September 2017,

http://edocs.nps.edu/npspubs/institutional/newsletters/strategic\%20insight/2007/gilpinJan07.pdf. Grabosky, P. (1994) Green markets: Environmental regulation by the private sector $\square$ aw and Policy, 16(4): 420448.

Grabosky, P. (1995) Dsing non-governmental resources to foster regulatory compliance $\square$ Governance: An International Journal of Policy and Administration, 8(4): 527550.

House of Commons Foreign Affairs Committee (2012) Piracy off the coast of Somalia. Viewed 17 September 2017,

www.publications.parliament.uk/pa/cm201012/cmselect/cmfaff/1318/1318.pdf.

International Association of Classification Societies (2009) Charter of the International

Association of Classification Societies. Viewed 15 September 2017,

www.iacs.org.uk/media/4422/iacs-charter-and-annexes-2009-rev5-june-2017.pdf.

The International Institute for Strategic Studies (2004) Piracy and maritime terror in Southeast Asia: Dire straits. Strategic Comments, 10(6): 12

129 International Maritime Bureau (2006) Piracy and armed robbery against ships: Annual report 1 January 31 December 2005. Essex: International Chamber of Commerce.

International Maritime Bureau (2011) Piracy and armed robbery against ships: Annual report 1 January 31 December 2010. Essex: International Chamber of Commerce.

International Maritime Bureau (2012) Piracy and armed robbery against ships: Annual report 1 January 31 December 2011. Essex: International Chamber of Commerce.

International Maritime Bureau (2013) Piracy and armed robbery against ships: Annual report 1 January 31 December 2012. Essex: International Chamber of Commerce.

International Maritime Bureau (2017) Piracy and armed robbery against ships: Annual report 1 January 31 December 2016. Essex: International Chamber of Commerce.

International Maritime Organization (2001) Measures to prevent the registration of phantom ships. London: International Maritime Organization.

International Maritime Organization (2002) International code for the security of ships and port facilities (ISPS), Chapter Xi-2 of the international convention for the safety of life at sea. London: International Maritime Organization.

International Maritime Organization (2009a) Protection of vital shipping lanes: Sub-regional meeting to conclude agreements on maritime security, piracy and armed robbery against ships for states from the Western Indian Ocean, Gulf of Aden and Red Sea Areas. London: International Maritime Organization.

International Maritime Organization (2009b) Information on internationally recommended transit corridor for ships transiting the Gulf of Aden. London: International Maritime Organization.

International Maritime Organization. (2009c) Piracy and armed robbery against ships: Outcome of the contact group on piracy off the coast of Somalia best management practices to deter piracy in the Gulf of Aden and off the coast of Somalia. London: International Maritime Organization.

International Maritime Organization (2011a) Report of the maritime safety committee on its 89th Session, MSC 89/25. London: International Maritime Organization.

International Maritime Organization (2011b) Revised interim guidance to ship owners, ship operators and ship masters on the use of privately contracted armed security personnel on board ships in the high risk area. London: International Maritime Organization.

International Maritime Organization (2011c) Revised interim recommendations for flag states regarding the use of privately contracted armed security personnel on board ships in the high risk area. London: International Maritime Organization.

International Maritime Organization (2011d) Interim recommendations for port and coastal states regarding the use of privately contracted armed security personnel on board ships in the high risk area. London: International Maritime Organization.

International Maritime Organization (2015) Djibouti code of conduct: Newsletter edition 4, November 2014 [August 2015. Viewed 17 September 2017,

www.imo.org/en/OurWork/Security/PIU/Documents/DCoC\%20Newsletter\%20(2015).pdf. 
International Maritime Organization (2017) Djibouti code of conduct. Viewed 15 September 2017, www.imo.org/en/OurWork/Security/PIU/Pages/DCoC.aspx.

Kelly, T. (2012) The US governmentSapproach to countering Somali piracy. Viewed 15 September 2017,

https://web.archive.org/web/20130102190826/www.state.gov/t/pm/rls/rm/199929.htm.

Lennox, P. (2008) Contemporary piracy off the horn of Africa. Calgary: Canadian Defence and Foreign Affairs Institute. Viewed 15 September 2017,

http://citeseerx.ist.psu.edu/viewdoc/download?doi=10.1.1.357.7032\&rep=rep1\&type=pdf. 130 Lessons from Piracy (2017) FAQs. Viewed 15 September 2017, www.lessonsfrompiracy.net/faq/.

Lindley, J. (2015) Somali piracy: A criminological perspective. London, UK: Routledge. Lindley, J. and Techera, E.J. (2017) Overcoming complexity in illegal, unregulated and unreported fishing to achieve effective regulatory pluralism $\square$ Marine Policy, 81: 71709.

Liss, C. (2007) The roots of piracy in Southeast Asia. Viewed 17 September 2017, www.nautilus.org/publications/essays/apsnet/policy-forum/2007/the-roots-of-piracy-insoutheast-asia.

Lloyds Joint War Committee (2015) Hull war, piracy, terrorism and related perils: Listed areas. Viewed 17 September 2017,

www.Imalloyds.com/AsiCommon/Controls/BSA/Downloader.aspx?iDocumentStorageKey=001f4 a07-7dde-46fb-9c16-770a419a2d0b\&iFileTypeCode=PDF\&iFileName=JWLA022.

Loughlin, M. and Scott, C. (1997) The regulatory stateDn P. Dunleavy , A. Gamble , I. Holliday , and G. Peele (eds), Developments in British Politics. Basingstoke, UK: Macmillan, pp. 205219.

Maritime Security Centre Horn of Africa (2016) About MSCHOA and OP ATALANTA. Viewed 15 September 2017, www.mschoa.org/on-shore/about-us.

Miller, J. (2010) Loaded: Freighters ready to shoot across pirate bow. Viewed 15 September 2017, www.wsj.com/articles/SB126265833983415885.

Mo, J. (2002) Options to combat maritime piracy in Southeast Asia[Ocean Development \& International Law, 33(2): 324B58.

Naqvi, M. (2012) India, Italy wrangle over Indian fishermen killing. Viewed 17 September 2017, www.cnsnews.com/news/article/india-italy-wrangle-over-indian-fishermen-killing.

North Atlantic Treaty Organization (2010) Maritime security: NATO and EU roles and coordination. Viewed 15 September 2017,

https://web.archive.org/web/20170215033212/www.nato-pa.int/default.asp?SHORTCUT=2087.

North Atlantic Treaty Organization (2016) Counter-piracy operations. Viewed 17 September

2017, www.nato.int/cps/en/natohq/topics_48815.htm.

Oceans Beyond Piracy (2013) The economic cost of Somali piracy 2012: Summary report.

Viewed 17 September 2017,

http://oceansbeyondpiracy.org/sites/default/files/ecop2012final_2.pdf.

Oceans Beyond Piracy (2017) The economic cost of Somali piracy 2016: Summary report.

Viewed 17 September 2017, http://oceansbeyondpiracy.org/reports/sop/east-africa.

OCEANUSLive.org (2012) Weekly piracy update. Viewed 17 September 2017,

http://us4.campaign-

archive2.com/?u=eff92c4124a86ce15ee04f687\&id=301b638b05\&e=1f92a3d7ac.

Office of the Inspector of Transport Security (2010) International piracy and armed robbery at

sea security inquiry report. Canberra: Department of Infrastructure, Transport, Regional

Development and Local Government.

Onuoha, F. (2009) Sea piracy and maritime security in the Horn of Africa: The Somali coast and Gulf of Aden in perspective DAfrican Security Review, Institute for Security Studies, 18(3): 3145. Puchala, D. (2005) Of pirates and terrorists: What experience and history teach $\square$ Contemporary Security Policy, 26(1): 124.

Quince, A. , Phillips, K. , and Evans, K. (2011) Somali pirates. Viewed 17 September 2017, www.abc.net.au/rn/rearvision/stories/2011/3185817.htm.

131 Roth, M. (2010) Crime and punishment: A history of the criminal justice system. Victoria, Australia: Wadsworth-Cengage.

Ruimin, H. (2012) The utility of seapower: The battle of the Atlantic and the Second World War in Europe Pointer: The Journal of the Singapore Armed Forces, 38(4).

Sampson, D. (2009) USAFRICOMErole in counter-piracy operations in the Horn of Africa. Viewed 15 September 2017, www.hsdl.org/?view\&did=734063.

Shipping Online (n.d.) Low and slow ships vulnerable, but pirates spot false moves. Viewed 15 September 2017, www.shippingonline.cn/news/newsContent.asp?id=11055.

The Strategist (2009) Private security companies called in to combat Somali piracy. Viewed 17 September 2017,

https://web.archive.org/web/20170502150029/www.ctc.usma.edu/posts/piracy-in-the-horn-ofafrica-a-growing-maritime-security-threat. 
United Kingdom Maritime Trade Operations (2017) About UKMTO. Viewed 15 September 2017, www.ukmto.org/about-ukmto.

United Nations (1982) United Nations convention on the law of the sea. Viewed 15 September 2017, www.un.org/depts/los/convention_agreements/texts/unclos/unclos_e.pdf.

United Nations Secretary-General (2010) Secretary-General remarks to the General Assembly informal meeting on piracy. Viewed 15 September 2017,

www.un.org/sg/en/content/sg/statement/2010-05-14/secretary-general-remarks-generalassembly-informal-meeting-piracy.

United Nations Security Council (2008) Resolution 1851, S/RES/1851. New York: United Nations.

United Nations Security Council (2015) Resolution 2246, S/RES/2246. New York: United Nations.

United Nations Security Council (2016) Resolution 2316, S/RES/2316. New York: United Nations.

Young, A. (2007) Contemporary maritime piracy in Southeast Asia: History, causes and remedies. The Netherlands: IIAS.

\section{Old wine, opaque bottles?}

Akdeniz, Y. (2016) Internet child pornography and the law: National and international responses, New York: Routledge.

Apple (2016) A message to our customers. Viewed 24 October 2017, www.apple.com/customer-letter/.

Australian Communications and Media Authority (2011) ACMA fighting online child abuse, media release 15 September 2011. Viewed 24 October 2017,

www.acma.gov.au/theACMA/acma-media-release-952011-15-september-acma-fighting-onlinechild-abuse.

Australian Communications and Media Authority (2014) ACMA hotline steps up fight against child exploitation material, media release 7 April 2014. Viewed 24 October 2017,

www.acma.gov.au/Citizen/Internet/esecurity/Staying-safe-online/acma-hotline-steps-up-fightagainst-child-exploitation-material.

AFP (n.d.) Online child sex exploitation. Viewed 24 October 2017,

https://forms.afp.gov.au/online_forms/ocset_ispich_form.

Attorney-GeneralsDepartment (n.d.a) Data retention. Viewed 24 October 2017,

www.ag.gov.au/dataretention.

Attorney-Generals Department (n.d.b) Cybercrime. Viewed 24 October 2017,

www.ag.gov.au/CrimeAndCorruption/Cybercrime/Pages/default.aspx.

Ayling, J. , Grabosky, P.N. and Shearing, C. (2009) Lengthening the arm of the law: Enhancing police resources in the twenty-first century. Cambridge UK: Cambridge University Press.

Bronitt, S. (1993a) Defending Giorgianni. Part one: The fault required for complicity $\square$ Criminal Law Journal, 17(4): 2422663.

Bronitt, S. (1993b) Defending Giorgianni. Part two: New solutions for old problems in complicity $\square$ Criminal Law Journal, 17(5): 3053118.

Canadian Civil Liberties Association (2014) A win at the Supreme Court on Internet privacy/ Viewed 24 October 2017, https://ccla.org/a-win-at-the-supreme-court-on-internet-privacy/.

Chang, L.Y.C. , Zhong, L. and Grabosky, P. (2016) Ditizen co-production of cyber security: Selfhelp, vigilantes and cybercrime $R$ Regulation and Governance, accepted, doi:

$10.1111 /$ rego.12125.

145 Crew, B. (2016) This Russian app lets you take photos of strangers and identify them online $\square$ Science Alert, 19 May. Viewed 24 October 2017, www.sciencealert.com/this-russianapp-lets-you-take-photos-of-strangers-and-identify-them-online.

Ehrlich, P. (2002) Dommunications Decency Act 230 BBerkeley Technology Law Journal, 17(1):

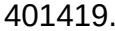

Grabosky, P. (1994) Bleyond the regulatory state $\square$ Australian and New Zealand Journal of Criminology, 27(2): $192 \mathbb{1 9 7 .}$

Grabosky, P. (1995) Using non-governmental resources to foster regulatory compliance $\square$ Governance, 8(4): 527550.

Grabosky, P. (2001) Dirtual criminality: Old wine in new bottles? \$ocial and Legal Studies, 10(2): 243249.

Grabosky, P. (2004) Пloward a theory of public/private interaction in policing $D n$ J. McCord (ed),

Beyond empiricism: Institutions and intentions in the study of crime. New Brunswick, NJ: 
Transaction Publishers, pp. 6981.

Grabosky, P. (2007) Electronic crime. Upper Saddle River, NJ: Pearson Prentice Hall.

Grabosky, P. (2016) Cybercrime. New York: Oxford University Press.

Grabosky, P. and Smith, R. (1998) Crime in the digital age: Controlling telecommunications and cyberspace illegalities. Leichhardt, NSW: The Federation Press.

Hill, S. (2015) Bow much do online advertisers really know about you? We asked an expert $\square$ Digital Trends, 27 June. Viewed 24 October 2017, www.digitaltrends.com/computing/how-doadvertisers-track-you-online-we-found-out/.

Johnston, C. (2016) Dux captured: The simple error that brought down the worldslsorst hurtcore paedophile CCanberra Times, 14 May. Viewed 24 October 2017,

www.canberratimes.com.au/national/lux-captured-the-simple-error-that-brought-down-theworlds-worst-hurtcore-paedophile-20160513-goum54.html.

Kerr, I. and Gilbert, D. (2004) The role of ISPs in the investigation of cybercrime $D n$ T. Mendina and J. Britz (eds), Information ethics in the electronic age. North Carolina: McFarland Press, pp. $163 \mathbb{1 1 7 2 .}$

McDonald, L. (2015) Everything youre been told about data retention is wrong $\square$ Gizmodo.au, 19 October. Viewed 24 October 2017 www.gizmodo.com.au/2015/10/everything-youve-been-toldabout-data-retention-is-wrong/.

National Public Radio (2015) Infiltrating the Dark Net, Where criminals, trolls and extremists reign. Viewed 24 October 2017, www.npr.org/sections/alltech-

considered/2015/06/03/411476653/infiltrating-the-dark-net-where-criminalstrolls-and-extremistsreign.

Nigerian Criminal Code (n.d.) Nigerian scams. Viewed 24 October 2017,

www.scamwatch.gov.au/types-of-scams/unexpected-money/nigerian-scams.

Office of the eSafety Commissioner (n.d.) About the office. Viewed 24 October 2017,

https://esafety.gov.au/.

Organisation for Economic Co-operation and Development (2010) The economic and social role of Internet intermediaries. Viewed 24 October 2017,

www.oecd.org/internet/ieconomy/44949023.pdf.

Palfrey, T. (1997) Bornography and the possible criminal liability of Internet service providers

under the obscene publication(s) and Protection of Children Act $\square$ nformation and

Communications Technology Law, 6(3): 187 प199.

Parliament of Australia. (2015a) Inquiry into the use of subsection 313(3) of the

Telecommunications Act 1997 by government agencies to disrupt the operation of illegal online services. Viewed 24 October 2017,

www.aph.gov.au/Parliamentary_Business/Committees/House/Infrastructure and Communicati ons/Inquiry_into_the_use_of_section_313_of_the_Telecommunications_Act_to_disrupt_the_op eration_of_illegal_onTine_services.

146 Parliament of Australia (2015b) Advisory report on the Telecommunications (Interception and Access) Amendment (Data Retention) Bill 2014. Viewed 24 October 2017,

www.aph.gov.au/Parliamentary_Business/Committees/Joint/Intelligence_and_Security/Data_Re tention/Report.

Richardson, M. (2012) Why policy matters: Google Inc v. Australian Competition and Consumer Commission $\square$ Sydney Law Review, 34(3): 587598.

Smith, R. , Grabosky, P. and Urbas, G. (2014) Cyber criminals on trial. Cambridge, UK:

Cambridge University Press.

Telstra Corporation (n.d.) Transparency at Telstra. Viewed 24 October 2017, www.telstra.com.au/privacy/transparency.

Urbas, G. (2015a) Cybercrime: Legislation, cases and commentary. Chatswood, NSW: Lexis Nexis Butterworths.

Urbas, G. (2015b) Complicity in cyberspace: Applying doctrines of accessorial liability to online groups $\square$ n R. Smith , R. Chak-Chung Cheung and L. Yiu-Chung Lau (eds), Cybercrime risks and responses: Eastern and Western perspectives. New York: Palgrave Macmillan, pp. 194205. Wall, D. (2007) Cybercrime: The transformation of crime in the digital age. Cambridge UK: Polity Press. 


\section{Internet vigilantism}

AppleDaily (2013) A girl committed suicide after being accuse for stealing $\square A p p l e D a i l y, ~ 16$

December. Viewed 26 June 2016,

https://hk.news.appledaily.com/international/daily/article/20131216/18553254.

Ayers, I. and Braithwaite, B. (1992) Responsive regulation: Transcending the deregulation debate. New York: Oxford University Press.

Barak, A. , Nissim, M.B. and Suler, J. (2008) Eostering empowerment in online support groups $\square$ Computers in Human Behavior, 24(5): 1867 [1883.

Barford, V. (2013) Who are vigilante group Letzgo Hunting?BBC, 19 September. Viewed 10 October 2017, www.bbc.com/news/magazine-24143991.

Bennett, T.H. , Holloway, K. and Farrington, D.P. (2008) Effectiveness of neighbourhood watch in reducing crime. Stockholm: National Council on Crime Prevention.

Brenner, S. (2007) Brivate-public sector cooperation in combating cybercrime: In search of a model[Journal of International Commercial Law Technology, 2(2): 5867.

Brenner, S. (2009) Cyberthreats: The emerging fault lines of the national state. Oxford: Oxford University Press.

Brenner, S. (2010) Cybercrime: Criminal threats from cyberspace. Santa Barbara, CA: Praeger. Broadhurst, R. (2006) Developments in the global law enforcement of cyber-crime $P$ Policing: An International Journal of Police Strategies and Management, 29(3): 408 433.

Brown, R. (1975) Strain of violence. New York: Oxford University Press.

Burrows, W. (1976) Vigilante. New York: Harcourt Brace Jovanovich.

Callahan, M. (2015) Schilling: Women should fight back against online harassment $\square$ New York Post, 8 March. Viewed 2 July 2016, http://nypost.com/2015/03/08/curt-schillings-war-againstdaughters-twitter-trolls/.

Chang, L.Y.C. (2012a) Cybercrime in the Greater China Region: Regulatory responses and crime prevention across the Taiwan Strait. Cheltenham: Edward Elgar.

Chang, L.Y.C. (2012b) Besponsive regulation and the reporting of information security incidents $\square$ ssues and Studies, 48(1): 85T19.

Chang, L.Y.C. (2012c) Dyber-conflict between Taiwan and ChinaロStrategic Insight, 10(1): 2635. Chang, L.Y.C. (2017) Cybercrime and cyber security in ASEANDn J. Liu, M. Travers and L. Chang (eds), Comparative criminology in Asia. New York: Springer, pp. $135 \mathbb{T 4}$.

Chang, L.Y.C. and Leung, A. (2015) An introduction of cyber-crowdsourcing (human flesh searching) in the Greater China region $\square$ n R. Smith , R. Cheung and L. Lau 159(eds),

Cybercrime risks and responses: Eastern and Western perspectives. New York: Palgrave, pp. 240252.

Chang, L.Y.C. and Poon, R. (2017) Online vigilantism: Attitudes and experiences of university students in Hong Kong $\mathrm{Cnternational} \mathrm{Journal} \mathrm{on} \mathrm{Offender} \mathrm{Therapy} \mathrm{and} \mathrm{Comparative}$ Criminology, 61(16): 1912 [1932.

Chang, L.Y.C. , Zhong, Y. and Grabosky, P. (2016) Ditizen co-production of cyber security: Selfhelp, vigilantes, and cybercrime $[$ Regulation \& Governance, accepted, DOI:

10.1111/rego.12125.

Cheung, A.S.Y. (2009) China Internet going wild: Cyber-hunting versus privacy protection $\square$ Computer Law \& Security Review, 25(3): 275079.

Downey, T. (2010) Chinaßlcyberposse $N$ New York Times Magazine, 3 March. Viewed 10 October 2017, www.nytimes.com/2010/03/07/magazine/07Human-t.html?pagewanted=all.

Dupont, B. (2004) Security in the age of networks Policing \& Society, 14(1): 7691.

Dupont, B. (2006) Bower struggles in the field of security: Implications for democratic transformation $\mathrm{n}$ J. Wood and B. Dupont (eds), Democracy, society and the governance of

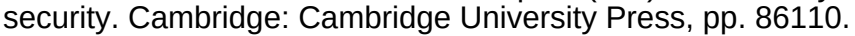

Glynn, C. (2013) Bloston marathon bombing Crowdsourcing $\square$ How netizens are using the Internet to help solve crimes $\square$ CBSNews. Viewed 10 July 2017, www.cbsnews.com/news/boston-

marathon-bombing-crowdsourcing-how-citizens-are-using-the-internet-to-help-solve-crimes/.

Golgowski, N. and Red, C. (2015) Eormer Red Sox pitcher Curt Schilling fires back after trolls $\square$ violent, sexual tweets about teen daughterDaily News, 3 March. Viewed 3 July 2017,

www.nydailynews.com/sports/baseball/ex-boston-pitcher-schilling-plays-hard-ball-trolls-article1.2134914.

Grabosky, P. (1992) Law enforcement and the citizen: Non-governmental participants in crime prevention and control Policing and Society, 2(4): 2492771.

Grabosky, P. (1995) Dsing non-governmental resources to foster regulatory compliance Governance: An International Journal of Policy and Administration, 8(4): 527550.

Grabosky, P. (2013) Bleyond responsive regulation: The expending role of non-state actors in

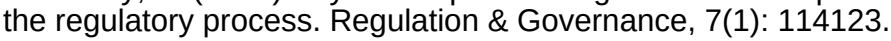


Grabosky, P. (2016) Cybercrime. New York: Oxford University Press.

Grabosky, P. (2017) Meta-regulation $\square$ n P. Drahos (eds), Regulatory theory: Foundations and applications. Canberra: ANU ePress, pp. $149 \mathbb{1 4 6 1 .}$

Hatton, C. (2014) Dhinas] Internet vigilantes and the Guman flesh search engine $B B C, 28$ January. Viewed 10 November 2017, www.bbc.com/news/magazine-25913472.

Herold, D.K. (2011) Buman flesh search engines: Carnivalesque riots as components of a Chinese democracy $\square$ n D.K. Herold and P. Marlot (eds), Online society in China: Creating, celebrating, and instrumentalising the online carnival. Oxford: Routledge, pp. $127 \mathbb{T 4 5 .}$

Hill, G. and Wall, D. (2015) Bow online vigilantes make paedophile policing more difficult $\square$ Conversation, 4 June. Viewed 10 September 2017, http://theconversation.com/how-onlinevigilantes-make-paedophile-policing-more-difficult-42562.

Huey, L. , Nhan, J. and Broll, R. (2013) Dppity civilians[and cyber-vigilantes $\square$ The role of the general public in policing cyber-crime CCriminology and Criminal Justice, 13(1): 8197.

160 Kuo, S. (2012) Bong Kong juveniles arrested for cat abusing $\square$ ChinaNews, 19 November. Viewed 20 September 2016, www.chinanews.com/ga/2012/11-19/4339531.shtml (in Chinese). Lee, D. (2013) Bloston bombing: How Internet detectives got it very wrong BBC, 19 April. Viewed 26 December 2016, www.bbc.com/news/technology-22214511.

Michaels, J. (2010) Deputizing homeland security पTexas Law Review, 88, 1435『473.

Nhan, J. , Huey, L. and Broll, R. (2017) Digilantism: An analysis of crowdsourcing and the Boston marathon bombings British Journal of Criminology, 57(2): 3412B61.

Ong, R. (2012) Online vigilante justice Chinese style and privacy in ChinaDnformation \& Communication Technology Law, 21(2): 127 प445.

Ransom, I. (2008) Mlan wins case vs நuman flesh search engine Reuters, 19 December. Viewed 12 September 2017, www.bbc.com/news/technology-22214511.

Steiner, P. (1993) On the Internet, nobody knows youre a dog $\square$ New Yorker, 5 July. Viewed 12 September 2017,

http://archives.newyorker.com/?iid=15713\&startpage=page0000063\#folio=CV1.

Stoll, C. (1989) The cuckooslegg: Tracking a spy through the maze of computer espionage. New York: Pocket Books.

Suler, J. (2004) The online disinhibition effect $\square$ CyberPsychology \& Behavior, 7(3): 321B26. Tapscott, D. and Williams, A.D. (2007) Wikinomics: How mass collaboration changes everything. London: Atlantic Books.

Wall, D.S. (2008/2010) Dybercrime and the culture of fear: Social science fiction(s) and the production of knowledge about cybercrime (revised May 2010) Dnformation, Communication \& Society, 11(6): 861884.

Wang, F.Y. , Zeng, D. , Hendler, J.A. , Zhang, Q. , Feng, Z. , Gao, Y. , Wang, Y. and Lai, G. (2010) A study of the human flesh search engine: Crowd-powered expansion of online knowledge $\subset$ Computer, 43(8): 4553.

Warren, S. and Brandeis, L. (1890) The right to privacy $\mathrm{Xu}, \mathrm{B}$. and Ji, S. (2008) Buman flesh search engine $\triangle A n$ Internet lynching? Xinhua News, 4 July. Viewed 17 September 2017, www.chinadaily.com.cn/china/2008-07/04/content_6821165.htm.

\section{The global anti-cybercrime network}

Anderson, M. (1989) Policing the world: Interpol and the politics of international police cooperation. Oxford: Clarendon Press.

Andreas, P. and Nadelmann, E. (2006) Policing the globe: Criminalization and crime control in international relations. Oxford: Oxford University Press.

Ayling, J. , Grabosky, P. and Shearing, C. (2009) Lengthening the arm of the law: Enhancing police resources in the twenty-first century. Cambridge: Cambridge University Press.

Bigo, D. (1999) Daison officers in Europe: New actors of the European security field? पh G.

Bruinsma and C. van der Vijer (eds), Public safety in Europe. University of Twente: Faculty of Public Administration, pp. 183R20.

Borgatti, S. and Everett, M. (1997) Detwork analysis of 2-mode data[Social Networks, 19(3): 243269.

Borgatti, S. , Everett, M. and Freeman, L. (2002) UCINET for Windows: Software for social network analysis. Harvard, MA: Analytic Technologies.

Boscovich, R. (2014) Written testimony of Richard Domingues Boscovich, Assistant General Counsel, Digital Crimes Unit, Microsoft Corporation [online] on the judiciary [subcommittee on crime and terrorism on taking down botnets: public and 
private efforts to disrupt and dismantle criminal networks. Viewed 9 August 2016, www.judiciary.senate.gov/imo/media/doc/07-15-14BoscovichTestimony.pdf.

Bowling, B. and Sheptycki, J. (2012) Global policing. London: SAGE Publications.

Breiger, R. (1974) The duality of persons and groups $\square$ Social Forces, 53(2): 181 प190.

Brewer, R. (2014) Policing the waterfront: Networks, partnerships, and the governance of port security. Oxford: Oxford University Press.

183 Broll, R. (2016) Collaborative responses to cyberbullying: Preventing and responding to cyberbullying through nodes and clusters $\square$ Policing and Society, 26(7): 735752.

Bullock, K. and Tilley, N. (2003) Erom strategy to action: The development and implementation of problem-oriented projects $\square \mathrm{n} \mathrm{K}$. Bullock and N. Tilley (eds), Crime reduction and problemoriented policing. Abingdon: Willan, pp. 89प125.

Chang, L.Y.C. , Zhong, L. and Grabosky, P. (2016) Ditizen co-production of cyber security: Selfhelp, vigilantes, and cybercrime $R$ Regulation and Governance, accepted, doi:

10.1111/rego.12125.

Clapton, G. , Cree, V. and Smith, M. (2013) Boral panics and social work: Towards a sceptical view of UK child protection $\square$ Critical Social Policy, 33(2): 1972117.

Cook, T. (2016) A message to our customers. Viewed 11 August 2016, www.apple.com/customer-letter/.

Deflem, M. (2002) Policing world society: Historical foundations of international police cooperation. New York: Oxford University Press.

den Boer, M. (2010) Dowards a governance model of police cooperation in Europe: The twist between networks and bureaucracies $\mathrm{nn}$ F. Lemieux (eds), International police cooperation: Emerging issues, theory and practice. Cullompton: Willan, pp. 4261.

Digital Trends Staff (2016) Apple vs. the FBI: A complete timeline of the war over encryption. Viewed 11 August 2016, www.digitaltrends.com/mobile/apple-encryption-court-order-news/.

Drahos, P. , Shearing, C. and Burris, S. (2005) Dodal governance as an approach to regulation $\square$ Australian Journal of Legal Philosophy, 30: 3058.

Dupont, B. (2004) Security in the age of networks $\square$ Policing and Society, 14(1): 76911.

Dupont, B. (2006) Delivering security through networks: Surveying the relational landscape of security managers in an urban setting $\square$ Crime, Law and Social Change, 45(3): $165 \square 84$.

Dupont, B. (2013) The proliferation of cyber security strategies and their implications for privacy $\square$ In K. Benyekhlef and E. Mitjans (eds), Circulation internationale de linformation et sCurit Montra: Les ditions Thmis, pp. 6780.

Dupont, B. (2017) Blots, cops, and corporations: On the limits of enforcement and the promise of polycentric regulation as a way to control large-scale cybercrime $\square$ Crime, Law and Social Change, 67(1): 97 M16.

Europol (2014) Worldwide operation against cybercriminals. Viewed 14 August 2016, www.europol.europa.eu/content/worldwide-operation-against-cybercriminals.

FBI (2014) International Blackshades malware takedown. Viewed 14 August 2016, www.fbi.gov/news/stories/international-blackshades-malware-takedown-1.

Gates, B. (2002) Bill Gates: Trustworthy Computing. Viewed 14 August 2016, www.wired.com/2002/01/bill-gates-trustworthy-computing.

Grabosky, P. (1995) Dsing non-governmental resources to foster regulatory compliance $\square$ Governance, 8(4): 527550 .

Grabosky, P. (2013) Bleyond responsive regulation: The expanding role of non-state actors in

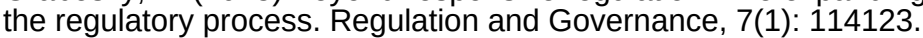

Gregory, F. (2000) Brivate criminality as a matter of international concern $\square$ n J. Sheptycki (eds), Issues in transnational policing. London: Routledge, pp. $100 \mathbb{3} 4$.

Hufnagel, S. (2013) Policing cooperation across borders: Comparative perspectives on law enforcement within the EU and Australia. Farnham: Ashgate.

Interpol (2013) Annual report 2013. Lyon: Interpol.

184 ITU (2010) ITU toolkit for cybercrime legislation. Geneva: International Telecommunication Union.

Jones, T. and Newburn, T. (1998) Private security and public policing. Oxford: Oxford University Press.

Marczak, B. and Scott-Railton, J. (2016) Keep calm and (dont) enable macros: A new threat actor targets UAE dissidents. Viewed 5 August 2016, https://citizenlab.org/2016/05/stealthfalcon/.

Marwick, A. (2008) To catch a predator? The MySpace moral panic. Viewed 11 August 2016, http://firstmonday.org/ojs/index.php/fm/article/viewArticle/2152.

Morn, F. (1982) The eye that never sleeps: A history of the Pinkerton national detective agency. Bloomington: Indiana University Press. 
Morselli, C. (2014) Crime and networks. New York: Routledge.

Nadelmann, E. (1993) Cops across borders: The internationalization of U.S. criminal law enforcement. University Park, PA: The Pennsylvania State University Press.

Nhan, J. and Huey, L. (2008) Bolicing through nodes, clusters and bandwidth $\square$ n S. LemanLanglois (eds), Technocrime: Technology, crime and social control. Cullompton: Willan, pp. 66877 .

OBeilly, C. (2010) The transnational security consultancy industry: A case of state-corporate symbiosis [Theoretical Criminology, 14(2): 1832110.

OBeilly, C. and Ellison, G. (2006) Eye spy private high: Re-conceptualizing high policing theory $\square$ The British Journal of Criminology, 46(4): 641660.

Perlroth, N. (2016) Governments turn to commercial spyware to intimidate dissidents $\square$ New York Times, 30 May. Viewed 6 August 2016,

www.nytimes.com/2016/05/30/technology/governments-turn-to-commercial-spyware-tointimidate-dissidents.html.

Raymond, M. and DeNardis, L. (2015) Multistakeholderism: Anatomy of an inchoate global institution $\square$ nternational Theory, 7(3): 5726116.

Scherrer, A. (2009) G8 against transnational organized crime. Farnham: Ashgate.

Shearing, C. and Wood, J. (2003) Dodal governance, democracy and the new denizens $\square$ Journal of Law and Society, 30(3): 400419.

Sheptycki, J. (2003) In search of transnational policing: Towards a sociology of global policing. Aldershot: Ashgate.

Slaughter, A.M. (2003) Global government networks, global information agencies, and disaggregated democracy MMichigan Journal of International Law, 24(4): $1041 \mathbb{1 0 0 7 6 . ~}$

Stalcup, M. (2013) நnterpol and the emergence of global policing Dn W. Garriott (eds), Policing and contemporary governance: The anthropology of police in practice. New York: Palgrave Macmillan, pp. 231261.

Stempel, J. (2016) Microsoft wins landmark case appeal over seizure of foreign emails. Viewed 13 August 2016, www.reuters.com/article/us-microsoft-usa-warrant-idUSKCNOZU1RJ.

UNODC (2013) Comprehensive study on cybercrime Draft. Viewed 28 July 2015, www.unodc.org/documents/organized-

crime/UNODC_CCPCJ_EG.4_2013/CYBERCRIME_STUDY_210213.pdf.

Wall, D. (2007) Bolicing cybercrimes: Situating the public police in networks of security within cyberspace $\square$ Police Practice and Research: An International Journal, 8(2): 183205.

Wasserman, S. and Faust, K. (1994) Social network analysis: Methods and applications. Cambridge: Cambridge University Press.

185 Weber, M. (2015 [1921]) Bureaucracy $\square n$ T. Waters and D. Waters (eds), Webers rationalism and modern society: New translations on politics, bureaucracy, and social stratification. New York: Palgrave Macmillan, pp. 73028.

Whelan, C. (2012) Networks and national security: Dynamics, effectiveness and organisation. London: Ashgate.

Whelan, C. (2014) Surveillance, security and sporting mega events: toward a research agenda on the organisation of security networks $\square$ Surveillance \& Society, 11(4): 392404.

Williams, M. and Levi, M. (2013) Multi-agency partnerships in cybercrime reduction: Mapping the UK information assurance network cooperation space $D$ nformation Management \& Computer Security, 21(5); 420 प443.

\section{Conclusions}

Ayres, I. and Braithwaite, B. (1992) Responsive regulation: Transcending the deregulation debate. New York: Oxford University Press.

Brewer, R. and Grabosky, P. (2014) The unraveling of public security in the United States: The dark side of police-community co-production DAmerican Journal of Criminal Justice, 39(1): 1391154.

Chang, L.Y. , Zhong, Y. and Grabosky, P. (2016) Citizen co-production of cyber security: Self-

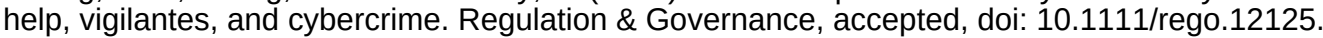
Grabosky, P. (1992) Law enforcement and the citizen: Non-governmental participants in crime prevention and control Policing and Society, 2(4): 249271.

Grabosky, P. (1995) Using non-governmental resources to foster regulatory compliance $\square$ Governance: An International Journal of Policy and Administration, 8(4): 527550.

Grabosky, P. (2001) Dirtual criminality: Old wine in new bottles?\$ocial and Legal Studies, 10(2): 243249. 
Grabosky, P. (2010) On the interface of criminal justice and regulation $\square \mathrm{n} \mathrm{H}$. Quirk , T. Seddon and G. Smith (eds), Regulation and criminal justice: Innovations in policy and research.

Cambridge: Cambridge University Press, pp. 72匹00.

Grabosky, P. (2013) Bleyond responsive regulation: The expanding role of non-state actors in the regulatory process $\mathrm{Regulation} \&$ Governance, 7(1): $114 \mathbb{1} 23$.

Grabosky, P. (2017) Meta-regulation Dn P. Drahos (eds), Regulatory theory: Foundations and applications. Canberra: ANU ePress, pp. 149匹61.

\section{Epilogue [Peter Nils Grabosky}

Australian Institute of Criminology (1990) Violence: Directions for Australia final report of the National Committee on violence. Canberra: Australian Government Publishing Service.

Beed, T.W. and Grabosky, P. (1983) Proceedings of the search conference on victim surveys in Australia. Sydney: University of Sydney Sample Survey Centre.

Broadhurst, R.G. (2001) Proceedings of the Asia cyber crime summit. Hong Kong: University of Hong Kong.

Broadhurst, R.G. (2004) Crime and its control in PR China: Proceedings of the annual symposium 2000R002. Hong Kong: The University of Hong Kong.

Broadhurst, R.G. (2006) Developments in the global law enforcement of cyber-crime + Policing: an International Journal of Police Strategies and Management, 29(3): 408433.

Broadhurst, R.G. and Grabosky, P. (2005) Cyber crime: The challenge in Asia. Hong Kong: University of Hong Kong Press.

Carcach, C. and Grabosky, P. (1998) Murder suicide in Australia. Canberra: Australian Institute of Criminology.

Grabosky, P. (1977) Sydney in ferment: Crime, dissent and official reaction, 1788ณ977.

Canberra: Australian National University Press.

Grabosky, P. (1984) The variability of punishment $\square$ n D. Black (ed), Toward a general theory of social control. Orlando: Academic Press, vol. I, pp. $163 \mathbb{1 1 8 9 .}$

Grabosky, P. (1988) बboriginal deaths in custody: The case of John Pat $\square$ Race and Class, 29(3): 8794.

Grabosky, P. (1989) Wayward governance: Illegality and its control in the public sector.

Canberra: Australian Institute of Criminology.

Grabosky, P. (2003) Dyber crime: Rapporteur巨reportDn R. Broadhurst (ed), Bridging the gap: A global alliance perspective on transnational organised crime. Hong Kong: Hong Kong Police Force, pp. 6368.

Grabosky, P. (2009) Community policing and peacekeeping. Florida: CRC Press.

Grabosky, P. (2016) Cybercrime. New York: Oxford University Press.

Gurr, T.R. , Grabosky, P. and Hula, R.C. (1977) The politics of crime and conflict: A comparative history of four cities. Beverly Hills: Sage Publications. 